\title{
MicroRNAs Involved in Metastasis of Hepatocellular Carcinoma: Target Candidates, Functionality and Efficacy in Animal Models and Prognostic Relevance
}

\author{
ULRICH H. WEIDLE $^{1}$, DANIELA SCHMID ${ }^{1}$, FABIAN BIRZELE $^{2}$ and ULRICH BRINKMANN ${ }^{1}$ \\ ${ }^{1}$ Large Molecule Research, Roche Pharma Research and Early Development ( $p$ RED), \\ Roche Innovation Center Munich, Penzberg, Germany; \\ ${ }^{2}$ Pharmaceutical Sciences, Roche Pharma Research and Early Development (pRED), \\ Roche Innovation Center Basel, Basel, Switzerland
}

\begin{abstract}
Hepatocellular carcinoma (HCC) is responsible for the second-leading cancer-related death toll worldwide. Although sorafenib and levantinib as frontline therapy and regorafenib, cabazantinib and ramicurimab have now been approved for second-line therapy, the therapeutic benefit is in the range of only a few months with respect to prolongation of survival. Aggressiveness of HCC is mediated by metastasis. Intrahepatic metastases and distant metastasis to the lungs, lymph nodes, bones, omentum, adrenal gland and brain have been observed. Therefore, the identification of metastasis-related new targets and treatment modalities is of paramount importance. In this review, we focus on metastasis-related microRNAs (miRs) as therapeutic targets for HCC. We describe miRs which mediate or repress HCC metastasis in mouse xenograft models. We discuss 18 metastasis-promoting miRs and 35 metastasis-inhibiting miRs according to the criteria as outlined. Six of the metastasispromoting miRs (miR-29a, -219-5p, -331-3p, 425-5p, -487a and $-1247-3 p$ ) are associated with unfavourable clinical prognosis. Another set of six down-regulated miRs (miR-101, $-129-3 p,-137,-149,-503$, and -630) correlate with a worse
\end{abstract}

This article is freely accessible online.

Correspondence to: Ulrich H. Weidle/Ulrich Brinkmann, Roche Innovation Center Munich, Roche Diagnostics GmbH, Nonnenwald 2, D-82372 Penzberg, Germany. Tel.: +49 8856604753, e-mail: weidle49@t-online.de/e-mail: ulrich.brinkmann@roche.com

Key Words: Antagomirs, intra-hepatic and distant metastasis, functional reconstitution of miRs, in vivo metastasis models, miRmimetics, metastasis-related in vivo models, prognostic correlations, subcutaneous implantation, tail vein injection, therapeutic modalities, therapeutic targets, review. clinical prognosis. We discuss the corresponding metastasisrelated targets as well as their potential as therapeutic modalities for treatment of HCC-related metastasis. A subset of up-regulated miRs -29a, -219-5p and -425-5p and downregulated miRs $-129-3 p$ and -630 were evaluated in orthotopic metastasis-related models which are suitable to mimic HCC-related metastasis. Those miRNAs may represent prioritized targets emerging from our survey.

Hepatocellular carcinoma (HCC) is the second-leading cause of cancer-related death worldwide (1). In the next couple of years, an annual incidence of one million cases is expected (1). Risk factors for $\mathrm{HCC}$ are non-alcohol steatohepatitis, hepatitis $\mathrm{B}$ and $\mathrm{C}$ virus (HBV/HCV), alcohol and aflatoxin (2). In Asia and Africa, $60 \%$ of HCC cases are associated with HBV, $20 \%$ are related to HCV (2). Patients with early- and intermediatestage $\mathrm{HCC}$ are treated with locoreginal therapies, those with advanced disease receive systemic treatment (3). Sorafenib, a multikinase tyrosine kinase inhibitor was the only approved agent between 2007 and 2016 (4). This agent gives rise to only marginal therapeutic benefit. Recently, therapeutic benefit was shown with multikinase inhibitors levantinib as frontline therapy, and regorafenib, cabazantinib and ramucirumab, a monoclonal antibody directed against vascular endothelial growth factor receptor 2 , as second-line therapies (4). In addition, nivolumab, a monoclonal antibody directed against programmed cell death protein 1 (PD1) has been granted accelerated approval by the Food and Drug Administration for treatment of $\mathrm{HCC}$ and other checkpoint inhibitors are undergoing phase III clinical trials for this indication (5). Unsupervised clustering has revealed three subtypes of HCC based on transcriptional profiling (6) and immune phenotyping with respect to lymphocyte infiltration has discovered HCC with high, moderate and excluded tumors, pointing to 
opportunities for personalized therapies for HCC (1, 4). Since the increment of therapeutic benefit for most drugs is relatively modest, identification of new targets and treatment modalities is of paramount importance. In this review, we focus on metastasis-related microRNAs (miRs) with in vivo efficacy in corresponding preclinical models of HCC.

HCC: Metastasis-related aspects. Several reports describe the study of HCC-related metastasis (7-12). Intrahepatic metastasis is an important route of metastasis of HCC. In this type of tumor, the blood flow is abnormal and the microvessels are extremely leaky, resulting in promotion of metastasis (13). The most frequent sites of distant metastases are the lung, lymph nodes, bones, omentum, adrenal glands and brain (7-12). Bone metastases of HCC are associated with particularly poor prognosis (14). The molecular mechanisms promoting intrahepatic metastases and dissemination to distant organs have only poorly been resolved.

microRNAs and their role in cancer. miRs are RNAs composed of 20-22 nucleotides which post-transcriptionally inhibit mRNA targets in several eukaryotic cell lines and tissues (15). They mediate degradation or translational inhibition of mRNAs by binding to complementary nts of corresponding mRNAs (15, 16). More than 1,000 miR-related genes have been identified in the human genome. The vast majority of them are transcribed by RNA polymerase II $(17,18)$. They are synthesized as primRNA precursors, processed in the nucleus by endonucleases such as RNase III DROSHA and microprocessor complex subunit Di George syndrome chromosomal region 8 (DGCR8), transported to the cytoplasm and cleaved by RNase III DICER (19). Finally, the mature miR duplex forms the RNA-induced silencing complex (RISC) which recognizes complementary sequences in the 3'- untranslated region (3'-UTR) of the target mRNAs, leading to their degradation or inhibition of their translation (20). A single miR can target multiple mRNAs and vice versa, multiple miRs can target the same mRNA (21). Therefore, inhibition or reconstitution of the function of miRs can interfere with several pathways and cellular networks (21). The relevance of miRs in cancer has been demonstrated first for $m i R-15 a$ and $-16-1$ in the pathogenesis of B-cell chronic lymphocytic leukemia $(22,23)$. The role of miRs in metastasis has been documented in several types of cancer (24-27). In this review, we focus on the role of miRs involved in metastasis of HCC. We have selected miRs with in vivo efficacy in preclinical metastasis-related models of $\operatorname{HCC}(28,29)$.

\section{Up-regulated miRs Mediating Metastasis}

miRs targeting tumor-suppressor genes. miR130b, -425-5p and -429 (Figures 1 and 2A) target phosphatase and tensin homolog (PTEN) which functions as a tumor suppressor in HCC and many other types of tumors $(30,31)$ miR-130b
(Figure 1) promotes proliferation and invasion of HepG2 and HCCLM3 cells in vitro and increases intrahepatic and lung metastases of these cell lines. Metastasis-mediated by $m i R$ $130 b$ is driven by PTEN/AKT/hypoxia-inducible factor- $1 \alpha$ (PTEN/AKT/HIF-1 $\alpha$ ) signaling (32). High levels of $m i R-130 b$ correlate with poor overall survival of patients with HCC (32). Stem cell antigen-1 (SCA1) and PTEN have been identified as direct targets of $m i R-425-5 p$ (Figures 1 and 2B) (33). SCA1 localizes to the nucleus and inhibits migration through transcription of integrin $\beta 1$ and binds to and inhibits myelin and lymphocyte protein by forming a ternary complex with serum response factor (34). $m i R-425-5 p$ (Figures 1 and $2 \mathrm{~B}$ ) promotes invasion and migration, but not proliferation of HCCML3 cells in vitro. It further mediates epithelial mesenchymal transition (EMT), local growth of HCCML3 in the spleen as well as intrahepatic metastasis (35). In addition to PTEN/AKT, integrin $\beta 1$ /focal adhesion kinase (FAK)/SRC (SRC), Ras homology family member A/cell-division control protein homolog 42 (RHOA/CDC42) and tissue inhibitor of metalloproteinases 2/matrix metalloproteinase 9 (TIMP2/ MMP9) signaling are affected by $m i R-425 p$ (35). It is is a marker for poor prognosis in patients with HCC and low longterm post-operative survival (35) and is up-regulated in HCC versus normal liver tissues according to data derived from The Cancer Genome Atlas (TCGA) (Figure 3).

miR-429 (Figure 1) induces invasion of HCCML3 and SMM-7721 cells in vitro (35). miR-429 activates phosphoinositol 3-kinase (PI3K)/AKT/glycogen synthase kinase $3 \beta(\mathrm{PI} 3 \mathrm{~K} / \mathrm{AKT} / \mathrm{GSK} 3 \beta)$ by inhibition of PTEN signaling, resulting in nuclear translocation of $\beta$-catenin (35) (Figure 1). In vivo, liver and lung metastases are enhanced by $m i R-429$ after tail vein injection of HCCML3 and MHCC97H cells transfected with $m i R-429$ (35).

$m i R-135 a$ (Figure 1) promotes invasion of HCC cell lines in vitro and reduction of its expression in CSQT-2 cells inhibits intrahepatic metastasis in vivo (36). Metastasis suppressor 1 (MTSS1) has been identified as a direct target of miR-135a (36). MTSS1 functions as a tumor suppressor in gastric cancer and $\mathrm{HCC}$, and interacts with the actin cytoskeleton $(36,37)$. Another investigation revealed downregulation of Krüppel-like factor 4 (KLF4) as a direct target of $m i R-135 a$ in SK-Hep1 HCC cells. KLF4 is a zinc finger transcription factor which is down-regulated by transforming growth factor $\beta$ (TGF $\beta$ ) and functions as a regulator of the cell cycle, proliferation and apoptosis, and as a tumor suppressor in HCC $(38,39)$. miR-135a mediated increased lung metastasis after tail vein injection of SK-Hep1 cells expressing $m i R-135 a$ in comparison to the control cell line (40).

miR-362-5p (Figure 1) is up-regulated in HCC, is associated with HCC progression (41) and promotes cell growth, invasion and migration of HL-7702 and SMC-7721 cells in vitro. Subcutaneous implantation of HepG2 cells expressing miR$362-5 \mathrm{p}$ results in increased lung metastasis in comparison to 


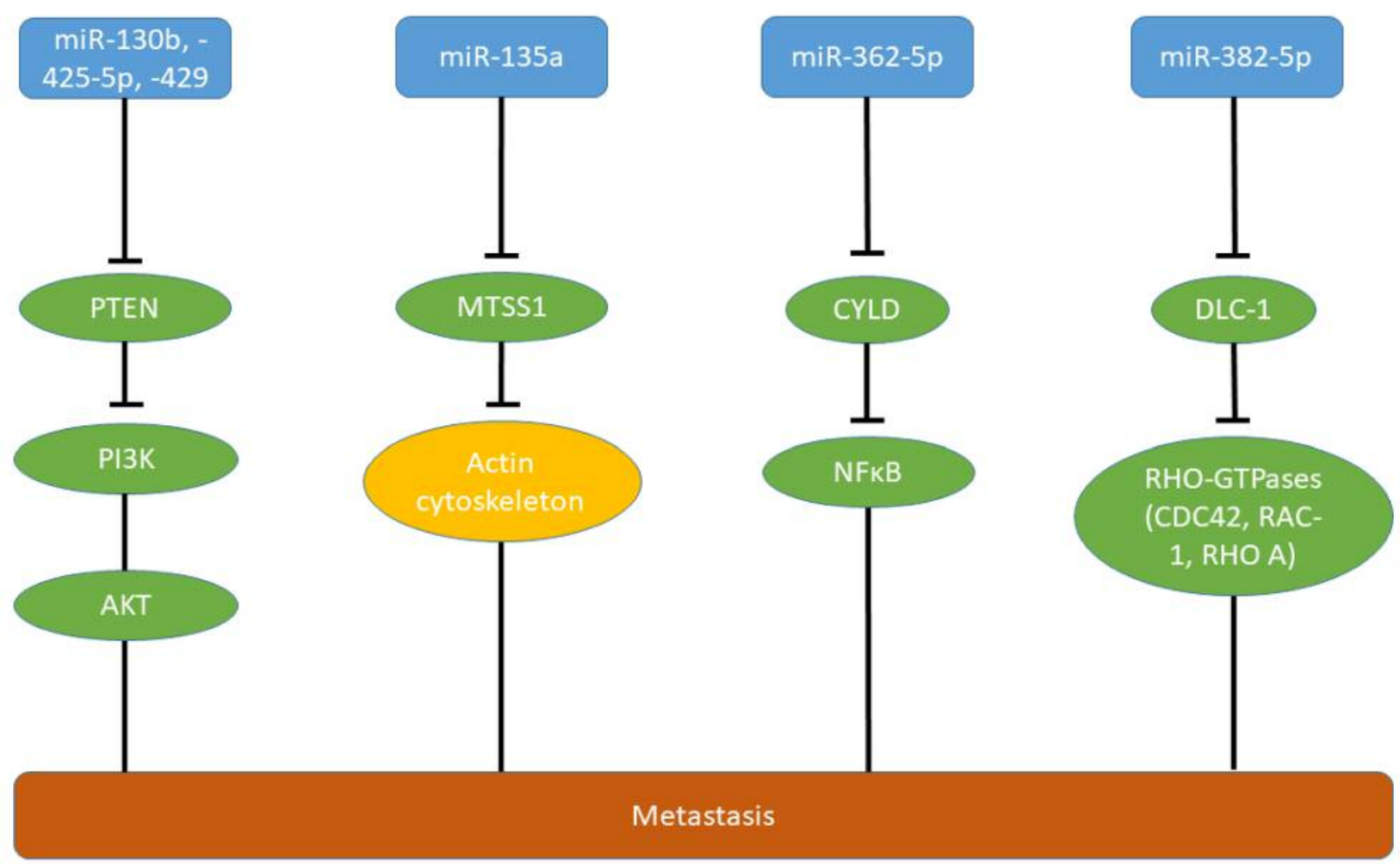

Figure 1. Micro-RNAs targeting tumor-suppressor genes in hepatocellular carcinoma. Up-regulation of miR-130, miR-135a, miR-362-5p, miR-382-5p, miR-425-5p and miR-429 promotes metastasis in HCC. AKT: Serine-threonine kinase AKT; CDC42: cell division control protein 42 homolog; CYLD: cylindromatosus; DLC-1: deleted in liver cancer 1; MTSS1: metastasis suppressor 1; NFKB: nuclear factor kB; PI3K: phosphoinositol-3-kinase; PTEN: phosphatase and tensin homolog; RAC1: Ras-related C3 botulinum toxin substrate 1; RHO A: RHO homolog gene family, member A.

the control cell line (41). $m i R$-362-5p targets cylindromatosus (CYLD), a deubiquitination enzyme which acts as a tumor suppressor in HCC and other types of cancer (42). CYLD interacts with various signaling pathways including TGF $\beta$, wingless-integrated (WNT) $/ \beta$-catenin and c-jun $N$-terminal kinase and inhibitsr $\mathrm{KB}(\mathrm{NFKB})$ signaling, resulting in cell proliferation, survival, invasion and metastasis (43).

$m i R-382-5 p$ (Figure 1) is an essential member of the HBV-regulated miR network. miR-382-5p promotes cell motility in vitro and lung metastasis of transfected HepG2 cells after tail vein injection (44). It targets deleted in liver cancer-1 (DLC1), a tumor-suppressor gene in liver cancer (45). DLC1 contains a Rho GTPase activating protein domain, a sterile alpha motif (SAM) and a star-related lipid transfer domain (START) domain (46). Loss of DLC1 leads to aberrant Rho GTPase function and contributes to abnormal migration and metastatic properties.

miRs interfering with cell signaling and cell cycle. miR-21: It has been observed that colony-forming unit endothelial cells (CFU-ECs) induced chemotaxis through RAs-related C3 botulinium toxin substrate 1 (RAC1) and MMP9 activation mediated by monocyte chemoattractant protein-1 (MCP1) released from CFU-ECs (47). From a mechanistic point of view this phenomenon is due to induction of $m i R-21$ by interaction of MCP1 with $\mathrm{C}-\mathrm{C}$ chemokine receptor 2 (CCR2) on tumor cells (47-49). miR-21 mediated metastasis by directly targeting Rho GTPase-activating protein 24 (ARHGAP24) and tissue inhitor of metalloproteinases 3 (TIMP3) $(47,50,51)$. Inhibition of ARHGAP24 activated RAC1 and inhibition of TIMP3 activates MMP9, both mediators of metastasis $(50,51)$. Huh 7 HCC cells co-cultured with CFU-ECs formed multiple nodules after orthotopic implantation into the liver of mice and inhibition of $m i R-21$ in Huh7 cells attenuated intrahepatic metastasis (47).

miR-29a (Figure 2A) promoted metastasis by silencing suppressor of cytokine signaling 1 (SOCS1), an inhibitor of metastatic signal transduction $(52,53)$, due to methylation of its DNA, and subsequent activation of Janus kinase (JAK)/signal transducer and activator of transcription 3 (STAT3) signaling (52). $m i R-29 a$ directly targets ten eleven translocation enzymes (TET) which convert 5-methylcytosine to 5-hydroxy- 


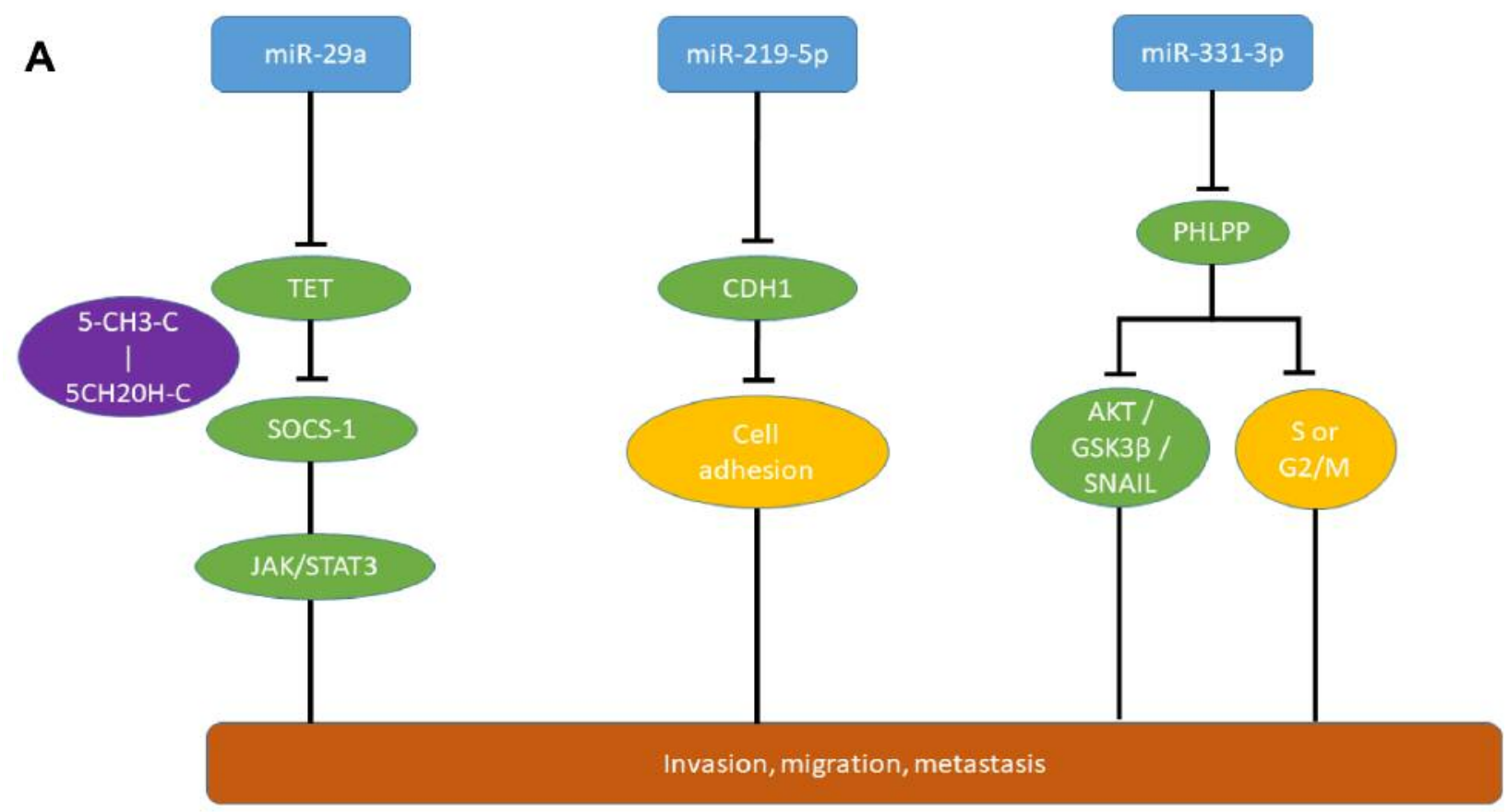

B

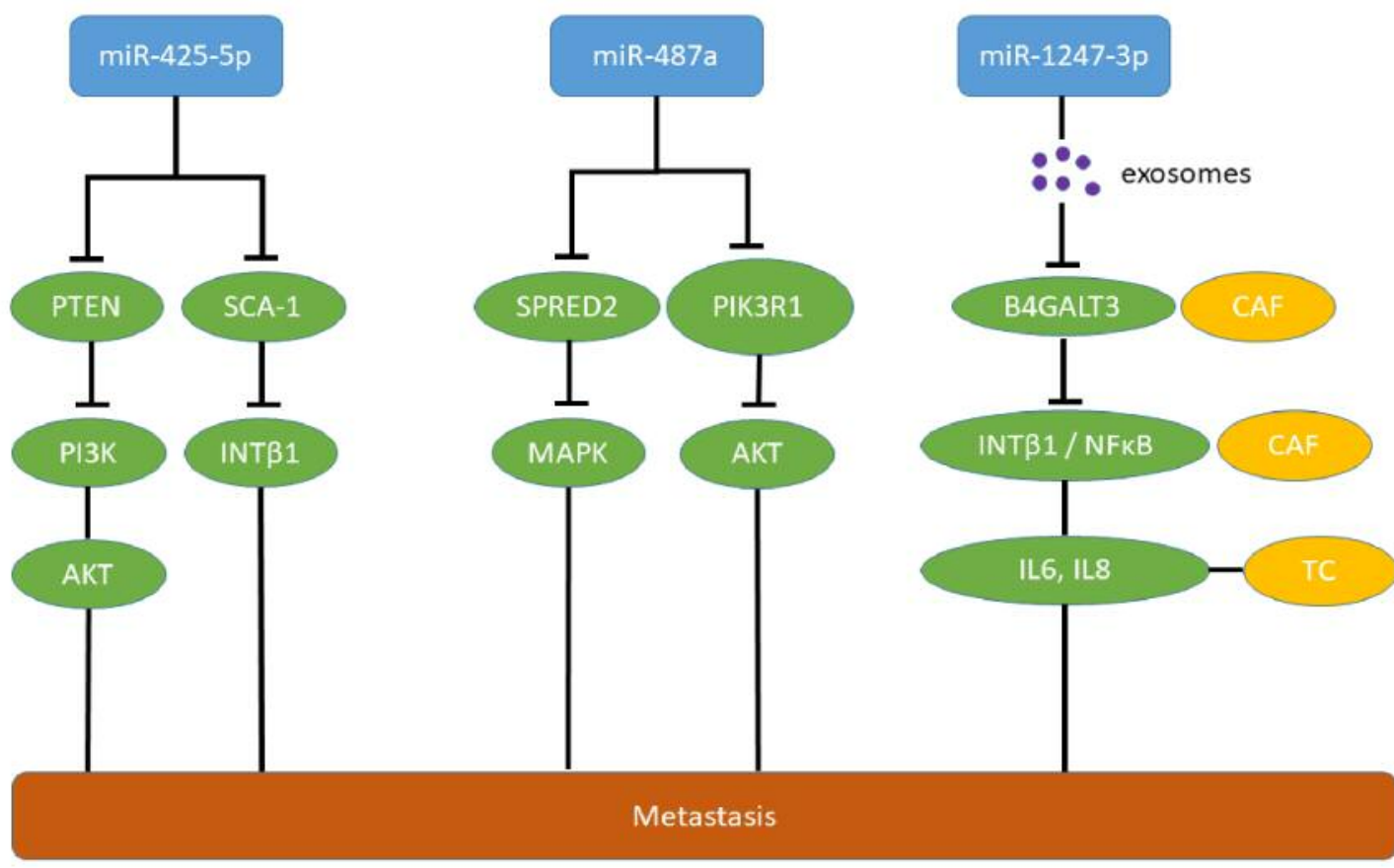

Figure 2. Metastasis-promoting miRs in hepatocellular carcinoma with in vivo activity in metastasis-related models and correlation to poor prognosis in patients. A: miR-29a, miR-219-5p and miR-331-3p; and B: miR-425-5p, miR-487a and miR-1247-3p. 5CH $\mathrm{OH}_{2} \mathrm{C}: 5 \mathrm{Hydroxymethyl-cytosine;}$ 5CH3-C: 5 methyl-cytosine; AKT: serine-threonine AKT; B4GALT3: $\beta$-1,4-galactosyltransferase 3; CAF: cancer-associated fibroblast; CDH1:

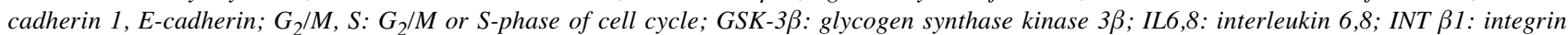
B1; JAK: janus kinase; MAPK: mitogen-activated protein kinase; NFkB: nuclear factor $k B$; PHLPP: PH domain and leucine rich repeat protein phosphatase; PI3K: phosphatidyl-inositol-3 kinase; PIK3R1: phosphatidyl-3 kinase regulatory subunit 1; PTEN: phosphatase and tensin homolog; SCA-1: stem cell antigen-1; SNAIL: transcription factor SNAIL; SPRED2: Sprouty-related and EvH1 domain-containing protein 2; STAT3: signal transducer and activator of transcription 3; TC: tumor cell; TET: ten-eleven translocation methylcytosine-dioxygenase. 
methylcytosine, resulting in inhibition of SOCS1 promoter demethylation (52-54). miR-29a promotes proliferation and invasion of HCC cell lines SMMC-7721 and HCCLM3 and increases tumor growth and lung metastasis of orthotopically implanted HCCLM3 and SMMC-7721 HCC cells transfected with $m i R-29 a(52)$. $m i R-29 a$ overexpression is correlated with poor clinical outcome in patients with $\mathrm{HCC}$ and inhibition of TET-SOCS mediated signaling in HCC tissues.

$m i R-135 b$ promoted migration and invasion of HCC cell lines SMMC-7721 and Huh7 (55). Orthotopic implantation of SMM-7721 cells transfected with $m i R-135 b$ revealed that $m i R-135 b$ induced formation of metastatic nodules in the liver (55). Reversion inducing-cysteine-rich protein with kazal motifs (RECK) and ectopic viral integration site 5 (EVI5) were identified as direct targets of $m i R-135 b(55)$. RECK is a membrane-anchored MMP inhibitor which acts as a key regulator of ECM integrity and angiogenesis (56). Suppression of RECK by $m i R-135 b$ resulted in activation of MMP2 and MMP9 (55). EVI5 is a regulator of cell-cycle progression and in addition functions as an inhibitor of Factin $(55,57)$. Down-regulation of EVI5 by $m i R-135 b$ increases invasion and migration of HCC cells (55).

$m i R-192-5 p$ promoted cell proliferation and metastasis of HCCLM3 cells, targeting the cancer stem cell (CSC) population of this cell line (58). Semaphorin 3A, a suppressor of angiogenesis (59) was identified as a direct target of $m i R-192-5 \mathrm{p}(58)$.

$m i R-331-3 \mathrm{p}$ (Figure 2A) was found to promote proliferation and migration of HCC cell lines HCCLM3, HepG2 and Huh7 (60). In these cell lines, miR-331-3p promoted intrahepatic metastasis and metastasis to the lungs after intrahepatic administration (60). PH domain and leucine repeat protein phosphatase (PHLPP) was identified as a direct target of $m i R-331-3 p(60,61)$. Down-regulation of PHLPP activates AKT/GSK-3 $\beta /$ SNAIL metastasis-promoting signaling (60) and mediates entry of HCC cells into the $S$ or $\mathrm{G}_{2} / \mathrm{M}$ phase of the cell cycle (60). Increased expression of $m i R-331-3 \mathrm{p}$ correlates with poor long-term survival of patients with HCC (60).

$m i R-487 a$ (Figure 2B) induced migration and wound healing in HCC cell lines such as HCCLM3 and HepG2 (62). An orthotopic mouse model with HCCLM3 cells injected into the liver revealed promotion of growth, intrahepatic metastasis and distant metastasis to the lungs mediated by $m i R-487 a$ (62). Sprouty-related EVH1 domain containing 2 (SPRED2) and phosphoinosite-3-kinase regulatory subunit 1 (PIK3R1) were identified as direct targets of $m i R-487 a(62)$. SPRED2 acts as an inhibitor of the mitogen-activated protein kinase (MAPK) cascade $(63,64)$ and deletion of $P I K 3 R 1$ has been shown to activate AKT and to inhibit PTEN $(65,66)$. $m i R-487 a$ is highly expressed in $\mathrm{HCC}$ and its expression correlates with poor postoperative prognosis of patients with HCC (62). Down-regulation of $m i R-487 a$ in HCC in comparison to normal liver was not confirmed through the TCGA data set (Figure 3).

miRs promoting EMT or affecting the ECM. Exosomes from highly miR-103-expressing HCC cells can interact with endothelial monolayers (67). miR-103 destabilizes tight junctions by targeting vascular endothelial cadherin, $\beta 120$ catenin and zona occludens 1, leading to destabilization of endothelial integrity (68). $m i R-103$ was also found to promote migration of HCC cells by targeting p120 catenin (67, 69). QGY-7703 cells transfected with miR-103 as xenografts gave rise to high rates of hepatic and pulmonary metastases in comparison to the control cell line (67).

miR-143 was found to be significantly up-regulated in patients with HBV-HCC (70). Transcription factor NFKB upregulated $m i R-143$, resulting in migration and invasion of HCC cell lines HepG2 and Huh7 (70). Fibronectin-type III domain containing 3B (FNDC3B) has been identified as a direct target of $m i R-143(70,71)$. FNDC3B was previously described to be down-regulated in tumor cells with high metastatic potential (72). HepG2 cells overexpressing $m i R$ 103 orthotopically transplanted into nude mice gave rise to intrahepatic and distant lung metastases in contrast to the control cell line (70).

$m i R-186$ is repressed by metastasis inhibiting runt-related transcription factor 3 (RUNX3) and inhibits E-cadherin (CDH1) expression by binding to the 3'-UTR of its mRNA (73). $m i R-186$ mimics reduced the expression of $\mathrm{CDH} 1$ in HCC cell lines HepG2 and Hep3B (73). RUNX3 suppressed migration, invasion and angiogenesis of human renal cell carcinoma (74) and the gene encoding RUNX3 is methylated in various types of cancer (75). miR-186 mimics abrogated inhibition of lung metastasis after tail vein injection of HepG2 cells expressing RUNX3 (73).

miR-219-5p (Figure 2A) can promote proliferation, cellcycle transition from $\mathrm{G}_{1}$ into $\mathrm{S}$-phase and increase the antiapoptotic potential of HepG2 and MHCC-97H cells (76). $C D H 1$ mRNA has been identified as a direct target of $m i R$ 219-5p (76). CDH1 inactivation results in loss of cell-cell adhesion which contributs to metastasis in a variety of tumors (77-79). Antagomirs of $m i R-219-5 \mathrm{p}$ transfected into MHCC$97 \mathrm{H}$ cells and implanted into the livers of nude mice reduced the volume of tumors and the total number of lung metastasis (76). Up-regulation of $m i R-219-5 \mathrm{p}$ is associated with metastasis and dismal prognosis in patients with HCC (76).

miRs promoting metastasis by interference with sugar-modifying enzymes. It is well documented that altered glycosylation of tumor cells can promote metastasis $(80,81)$. $m i R-23$ is upregulated in metastatic mouse HCC cell lines such as Hca-P and Hepa 1-6, and promotes migration in vitro (82). Subcutaneous injection of Hca-P cells transfected with a miR-23 mimic promoted metastasis to the inguinal lymph nodes (82). 
Mannoside acetylglucosaminyl-transferase 3 (MGAT3), an enzyme catalysing transfer of acetyl-glucose in a $\beta 1,4$ linkage to mannose on $\mathrm{N}$-glycans and thus forming a bisected acetylglucose structure, was identified as a direct target of $m i R-23$ (82). MGAT3 has been reported to inhibit cell migration and to modulate cell adhesion, indicating a relationship between aberrant glycosylation and metastasis (83).

Exosomes secreted from HCC cells in the pre-metastatic niche contain miR-1247-3p (Figure 2B) which activates fibroblasts in the neighourhood to cancer-associated fibroblasts promoting cancer progression by secreting pro-inflammatory cytokines such as interleukin (IL) 6 and IL8 (84). $m i R$-1247-3p targets $\beta 1,4$ galactosyltransferase 3 (B4GALT3) leading to activation of $\beta 1$ integrin-NFKB signaling in fibroblasts of the lung premetastatic niche of liver cancer (84). B4GALT3 transfers galactose to $\mathrm{N}$-acetylglu-cosamine to form $\mathrm{N}$ acetyllactosamine in glycosylated proteins (85). B4GALT3 suppresses integrin $\beta 1$-mediated phenotypes and metastasis (86, 87). Lung metastasis of subcutaneously implanted HCC cell line SMMC-7721 was promoted by intravenously administered exosomes from CSQT-2 and HCC-LM3 cells (84). In patients with HCC, high expression of $m i R-1247-3 p$ in exosomes shows a positive correlation with lung metastasis (84). $m i R-1247-3 \mathrm{p}$ was down-regulated in HCC compared to normal liver samples in the available TCGA data set (Figure 3).

\section{Down-regulated miRs Which Inhibit HCC Metastasis}

miRs affecting angiogenesis. Down-regulation of miR-100 and $m i R-125 b$ (Figure 4A) in HCC tissues is associated with the presence of blood vessels encapsulating tumor cells (VETCs) facilitating their entry into the bloodstream (88). In a mouse orthotopic xenograft model, expression of $m i R-100$ and $m i R$ $125 b$ suppressed VETC formation and abrogate VETCdependent metastasis (88). In xeno- and allografts expressing $m i R-100$ or miR-125b much lower rates of hepatic and pulmonary metastases were observed with human VETC-2 and mouse Hepa 1-6 cells in comparison to control cell lines (88). $m i R-100$ and $m i R-125 b$ inhibit VETC formation by attenuation angiopoietin 2 (ANGPTN 2) expression $(88,89)$ ). For $m i R$ $125 b$, ANGPTN2 has been identified as a direct target; $m i R$ 100 targets mammalian target of rapamycin (mTOR) directly, resulting in attenuation of ANGPTN2 expression $(88,90)$.

$m i R-125 a$ (Figure 4A) is down-regulated in HCC-related tissues and cell lines (91). Ectopic expression of $m i R-125 a$ inhibited proliferation of HepG2 and HCC-LM3 HCC cells and $m i R-125 a$ directly targets vascular endothelial growth factor (VEGF) and MMP11, both mediators of metastasis (91-94). Increased expression of VEGF in HCC is associated with high proliferation index and poor encapsulation of tumors $(92,93)$. HCC-LM3 cells expressing miR-125a showed reduced metastasis to the lungs and liver after tail vein injection (91).
miR-195 (Figure 4A) is down-regulated in HCC and is associated with worse prognosis (95). miR-195 inhibited HCC cell line QGY-7703 promoted migration of endothelial cells and suppresses in vitro migration and invasion of QGY7703 HCC cells (95). In an orthotopic xenograft model, $m i R$ 105 suppresses intrahepatic and pulmonary metastasis (95). miR-195 inhibits angiogenesis and metastasis by targeting VEGF, guanine nucleotide exchange factor VAV2 and cell division control protein 42 (CDC42) (95). VAV2 functions as a guanine nucleotide exchange factor and CDC42 is a member of the Rho family of GTPases. Both are involved in regulation of the cell cycle and in attenuating pro-invasive functions of the cytoskeleton (96).

miR-199a-3p (Figure 4A) is down-regulated in HCC and inhibits tumor-stroma cross-talk (97). VEGF is a direct target of $m i R-199 a-3 p$, which inhibits VEGF secretion from tumor cells as well as expression of VEGF receptors 1 and 2 on endothelial cells and thus restricts the cross-talk between tumor and endothelial cells (97). As further direct targets, hepatocyte growth factor (98) and MMP2 (99) have been identifed as mediators of metastasis. $m i R-199-3 \mathrm{p}$ inhibits growth and lung metastasis of SNU449 HCC cells subcutaneously implanted into nude mice (97).

miR-497 (Figure 4A) is down-regulated in HCC-related cells and tissues (100). Overexpression of miR-497 in Huh7 and PLC-PRF-5 HCC cell lines inhibits their migration, invasion and pro-angiogenic activity (100). miR-497transfected Huh7 cells gave rise to smaller tumors in comparison to the non-transfected cell line after subcutaneous implantation and reduced the number of lung nodules after tail vein injection (100). Direct inhibition of VEGF by $m i R-497$ inhibits angiogenesis. Astrocyte elevated gene 1 (AEG1) has been identified as another direct target of miR-497 (100). AEG1 promotes tumor cell invasion and metastasis by activation of $\mathrm{PI} 3 \mathrm{~K} / \mathrm{AKT}$ and $\mathrm{WNT} / \beta$-catenin pathways (100-102).

miRs interfering with signaling, cell cycle and cytoskeleton function. Ectopic expression of miR-7 reduced invasion and migration of QGY-7703 cells in vitro (103). Metastatic nodules in the lungs and the liver were repressed after tail vein injection of QGY-7703-miR-7 transfected HCC cells (103). Tumor growth of these cells was inhibited after scapular implantation in comparison to control cells (103). PI3K subunit delta, the major component of PI3K was identified as a direct target of miR-7 (103). Down-regulation of $m i R-7$ results in activation of AKT-mTOR signaling (104, 105). An inverse correlation between expression of $m i R-7$ and PIK3CD in clinical HCC specimens has been observed (103).

miR-10a inhibited metastasis of HCC-related QGY-7703 and HepG2 cells to the liver after intrasplenic implantation (106). EPH tyrosine kinase receptor EPH4 was identified as a direct target of miR-10a (106). Epha4 binds to EPH- 


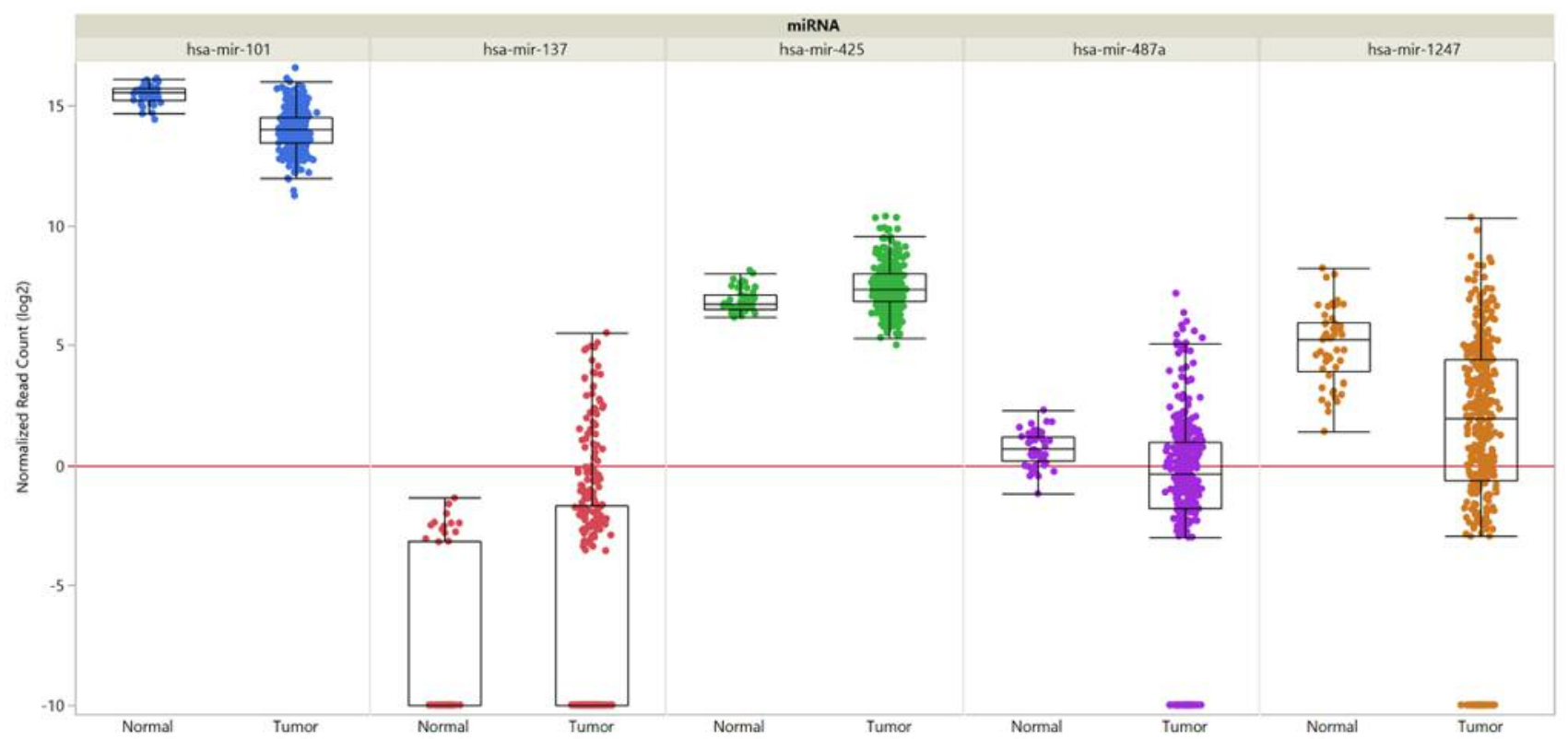

Figure 3. Expression of selected miRs in hepatocellular carcinoma compared to normal tissues. Data are shown for miR-101, miR-137, miR-425, $m i R-487 a$ and miR-1247. Data from 377 HCC samples and 50 normal liver samples derived from The Cancer Genome Atlas are shown. miR expression was quantified by RNA sequencing and is shown as log2 of randomized read counts. The red lines indicate lower versus higher expression. Expression data are shown as box plots. The line in the medium of the box represents the median value, the rectangles show the upper and lower $25 \%$ quartiles, and 50\% of all data points are included in the greater rectangle. All of the data points, except for the outliers are located within the upper and lower whiskers.

receptor-interacting proteins $\mathrm{A}$ and $\mathrm{B}$ and mainly affects cell shape and motility by regulating cytoskeletal organization and cell adhesion (106). $m i R-10 a$ and EPHA4 affect cell adhesion via the $\beta 1$ signaling pathway (106). miR-10a probably suppresses homing of metastatic HCC cells to distant organs (106).

$m i R-26 a$ is frequently down-regulated in HCC tissues and targets IL6/STAT3 and MYC/enhancer zeste homolog 2 (EZH2)-mediated metastasis $(107,108)$. In HCC cell lines HCC-LM3 and MHCC97-H, miR-26a induced $\mathrm{G}_{1}$ arrest and promotes apoptosis (108). In an intrahepatic nude mouse model, growth and metastasis to the lungs of HCC-LM3 and MHCC97-H cells were inhibited by miR-26a. These observations are based on direct inhibition of IL6 mRNA by $m i R-110$ (108). IL6 promotes tumor cell growth and invasion via STAT3 signaling in many types of tumors $(109,110)$. In a different system $m i R-26 a$ interfered directly with several targets such as cyclin-dependent kinase 8 (CDK8), p21 activated protein kinase 2 (PAK2) and EZH2 (108). Inhibition of CDK8, a co-activator of WNT signaling, results in reduced expression of c-MYC $(110,111)$. PAK2 mediates invasion of $\mathrm{HCC}$ cells by linking Rho GTPases to cytoskeleton reorganization during the metastatic process (112). EZH2, a member of the polycomb group of proteins can repress tumor suppressor miRs by H3K27-dependent and -independent mechanisms $(113,114)$.

TGF $\beta$ suppressed expression of $m i R-34 a$ and is associated with persistent presence of $\mathrm{HBV}$ in liver tissue (115). Chemokine (C-C motif) ligand 2 (CCL2) was identified as a direct target of $m i R-34 a$ (115). TGF $\beta$ induces production of CCL2 via suppression of $m i R-34 a(115,116)$. CCL2 functions as a recruiter of regulatory T-cells (117). In Hepa1-6 mouse HCC cells, tumor growth and metastasis to mouse liver and abdomen after intraplenic injection in immuno-competent mice was suppressed by overexpression of $m i R-34 a$ in these cells (115). Growth and metastasis to the lungs of fat padimplanted 4T1 murine breast cancer cells overexpressing $m i R$ $34 a$ was severely inhibited in immuno-competent mice in comparison to control cells (115). An inverse correlation between CCL2 level and miR-34a was found in HBV-HCC tumor samples. These results emphasize the importance of TGF $\beta-m i R-34 a-C C L 2$ signaling in HBV-HCC.

miR-100 inhibits invasion of Hepa 1-6 mouse and human QGY-7703 HCC cells in transwell assays and reduces the incidence of pulmonary metastases of miR-100 transfected and orthotopically implanted Hepa 1-6 cells (118). As direct targets of $m i R-100$, isoprenylcysteine carboxylmethyltransferase (ICMT) and RAC1, both promoters of metastasis, were 
identified (118). ICMT functions as a post prenylation processing enzyme which methylates a group of proteins including Rho GTPases and mediates activation of RAC1 (119, 120). RAC1 signaling promotes actin polymerization, subsequent lamellopodia formation and induces PI3K/AKT signaling $(121,122)$.

$m i R-101$ (Figure 4B) and $m i R-139$ target RHO-associated protein kinase 2 (ROCK2) $(123,124)$. ROCK2 is a downstream effector of RhoA GTPase and induces formation of stress fibers and focal adhesions by phosphorylating myosin light chains (125). ROCK2 confers motility and invasive capacity to $\mathrm{HCC}$ cell lines in vitro and in vivo and is frequently overexpressed in $\operatorname{HCC}(125,126)$. In addition to ROCK2, several additional targets for $m i R-101$, such as induced myeloid leukemia cell differentiation protein, cyclooxygenase 2, stathmin 1, EZH2 and FOS, all involved in proliferation, invasion and metastasis, have been identified (123). In vivo, upon transfection with $m i R-101$, the HCC cell line LM9 exhibited reduced metastatic colonization to the lungs and the liver after tail vein injection (123). miR-101 is frequently down-regulated in HCC patients with distant metastasis and predicts poor prognosis (123). According to data retrieved from TCGA, $m i R-101$ was down-regulated in HCC samples in comparison to normal liver tissues (Figure 3). miR-139 reduced migration, but had no impact on proliferation of SMMC-7721 and BEL-7402 HCC cell lines in vitro and suppressed lung metastasis of miR-139transfected orthotopically implanted MHCC97-H cells in comparison to control cells (124).

$m i R-129-3 p$ (Figure 4B) inhibited migration and invasion of HCC cell lines HCCLM3 and MHCC97-H in vitro and reduced intrahepatic and lung metastasis in nude mice (127). Aurora A, a serine-threonine kinase (128), has been identified as a direct target of $m i R-129-3 p$ (127). $m i R-129-3 p$ inhibits PI3K/AKT and p38/MAPK signaling (127). Expression of aurora A correlates with lymph node metastasis of HCC, its inhibition leads to reduced cell growth, proliferation and enhanced apoptosis in HCC (129, 130). Methylationdependent $m i R-129-3 \mathrm{p}$ down-regulation correlates with metastasis and poor prognosis of patients with HCC (127).

miRs-137 and miR-612. miR-137 (Figure 4B) inhibited proliferation and migration of SK-Hep1 and QGY-7703 HCC cells and reduceed liver and lung metastasis of HCC xenografts injected into the flanks of mice (131). AKT2 (132) has been identified as a target of miR-137 (131). Overexpression of AKT2 leads to up-regulation of $\beta 1$ integrins, increased invasion and metastasis in ovarian and breast cancer cells (133) and correlates with poor prognosis in HCC (134). Significant down-regulation of $m i R-137$ in HCC versus normal liver tissues was not demonstrated in TCGA data set (Figure 3). miR-612 also targets AKT2, is down-regulated in patients with metastatic HCC and inhibited metastatic foci of HCCLM3 cells in the liver and the lungs after tail vein injection (135).

miR-149 (Figure 4C) inhibited migration and invasion of HepG2 and MHCC97-H HCC transfectants and in vivo metastasis to the lungs of $m i R$-149-transfected HepG2 cells injected into the caudal veins was reduced (136). $\mathrm{Mg}^{2+} / \mathrm{Mn}^{2+}$ dependent protein phosphatase $1 \mathrm{~F}$ (PPM-1F) was identified as a target of $m i R-149$ (136). PPM-1F belongs to the protein phosphatase 2C family of serine-threonine protein phosphatases and acts as a mediator of motility and adhesion of cancer cells by regulating cytoskeleton remodeling (137, 138). $m i R-149$ is frequently down-regulated in HCC tissues and is associated with poor clinicopathological factors and low postoperative survival rate (136).

miR-150 suppressed proliferation, migration and invasion of MHCC97-H and SMMC-7721 HCC cell lines and in vivo lung metastases of i.v. injected miR-150-expressing MHCC97-H cells was inhibited in comparison to control cells (139). GRB2associated-binding-protein-1 (GAB1) was identified as a direct target of miR-150 (139). GAB1 functions as a scaffolding adaptor, is involved in tumorigenesis, invasion and metastasis, and can mediate activation of MAPK signaling $(140,141)$.

$m i R-188$ is frequently down-regulated in $\mathrm{HCC}$ and in vivo, HCCLM3 cells expressing $m i R-188$ gave rise to smaller tumors and intrahepatic and lung metastases were reduced (142). Fibroblast growth factor 5 was identified as a direct

Figure 4. miRs inhibiting metastasis of hepatocellular carcinoma xenografts. A: MicroRNAs attenuating angiogenesis and metastasis in hepatocellular carcinoma. Down-regulation of miR-100, miR-125a, miR125b, miR-195, miR-199-3p and miR-497 promotes angiogenesis and metastasis in hepatocellular carcinoma. B: Metastasis-inhibitory miRs in hepatocellular carcinoma with in vivo activity in a metastasis related model and correlation to poor prognosis in patients. miR-101, miR-129$3 p$ and miR-137. C: Further metastasis-inhibitory miRs in hepatocellular carcinoma with in vivo activity in a metastasis-related model and correlation to poor prognosis in patients. miR-149, miR-503 and miR630. AEG-1: Astrocyte-elevated gene 1; AKT: serine-threonine kinase AKT; ANGPTN-2: angiopoietin 2; ARFGEF 19: brefeldin-inhibited guanine nucleotide exchange protein 1; Aurora A: serine-threonine protein kinase aurora A; CDC42: cell division control protein homolog 42; COX2: cyclo-oxygenase 2; EMT: epithelial-mesenchymal transition; EZH2: enhancer of zeste homolog 2; FOS: transcription factor FOS; $H G F$ : hepatocyte growth factor; INT $\beta 1$ : integrin $\beta 1 ; M C L-1$ : induced myeloid leukemia cell differentiation protein 1; MLC-P: phosphorylated myosin light chain; MMP2,9: matrix metalloproteinases 2, 9; mTOR: mammalian target of rapamycin; $N F \kappa B$ : nuclear factor $\kappa B$; p38MAPK: p38 mitogen-activated protein kinase; PAK: p21-activated kinase; PI3K: phosphatidyl-inositol 3-kinase; PI3K: phosphoinositol-3-kinase; PPM$1 F$ : protein phosphatase $1 F$; RHO A: RAS homolog gene family, member A; ROCK2: RHO associated coil-coil-containing protein kinase 2; SLUG: transcription factor SLUG; STMN1: stathmin; VAV2: guanine nucleotide exchange factor VAV2; WNT: wingless-integrated. 


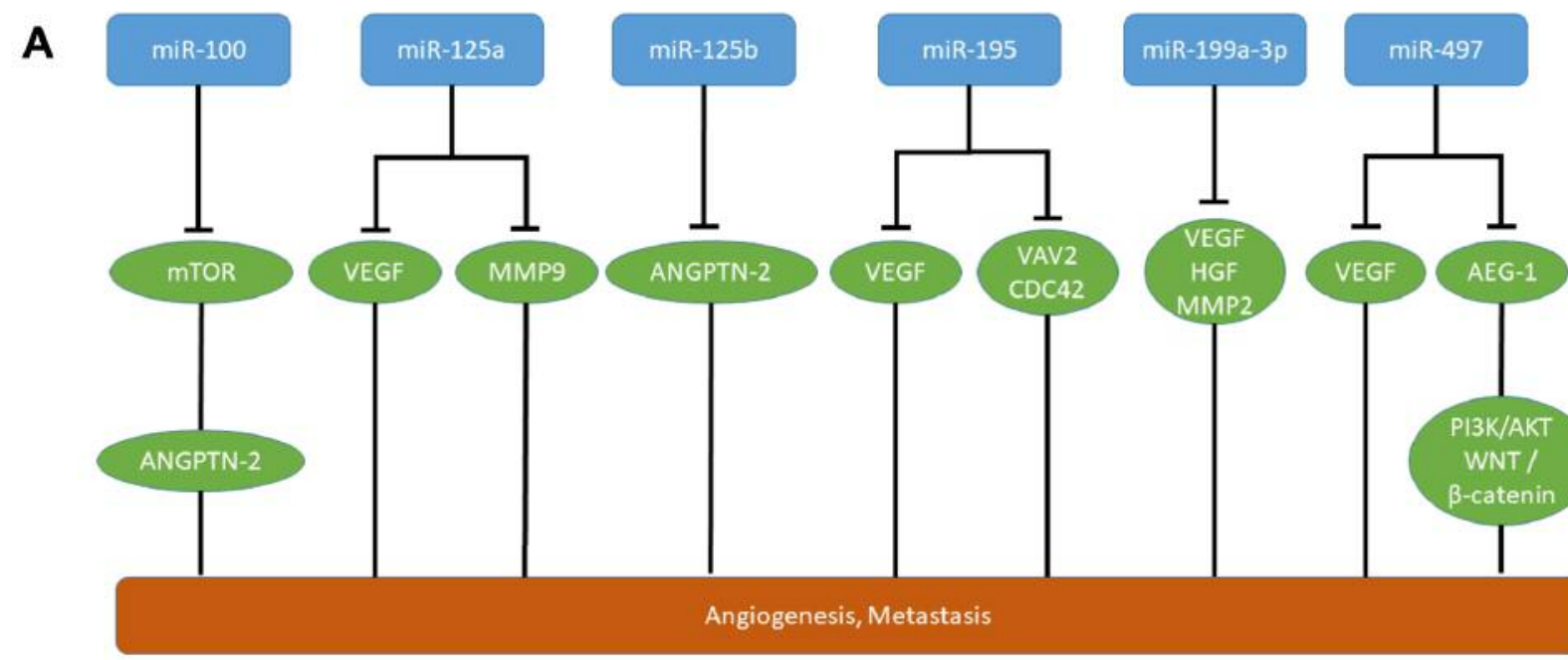

B

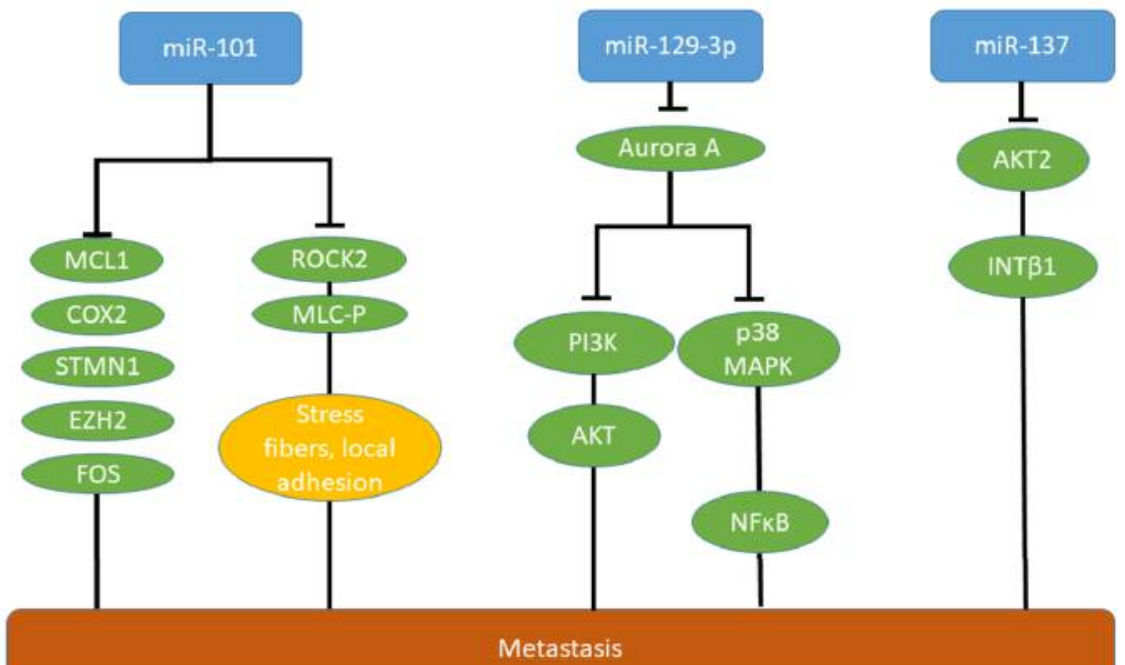

C

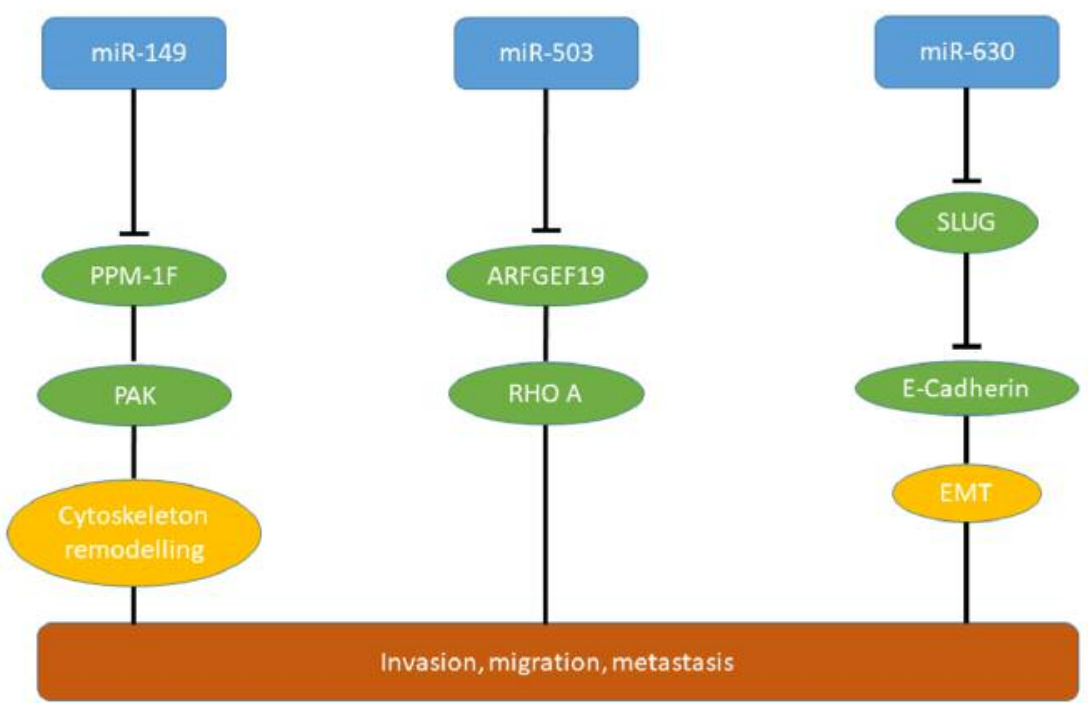


target of $m i R-188$ which attenuates MAPK signaling (142), and regulates tumor growth and invasion (143).

miR-345 inhibited liver metastasis of HCCLM3 cells after i.v. injection. Interferon regulatory factor (IRF1) was identified as a target of miR-345 (144). IRF1 functions as an oncogene which up-regulates p-mTOR, p-STAT3 and p-AKT and inhibits expression of SLUG, SNAIL and TWIST, modulators of migration and invasion (145). In a parallel approach, YES-associated protein (YAP1), a transcriptionregulating oncogene in human cancer, promoting growth and metastasis of HCC cells (146-148), was identified as a target of $m i R-345$. Cell migration and invasion of MHCC97-H cells overexpressing $m i R-345$ as well as lung metastasis of these cells after tail vein injection were inhibited in comparison to control cells (144).

$m i R-367$ inhibited tumor growth, intra-hepatic and lung metastatic foci of HCC cell lines and targets mouse double minute 2 homolog (MDM2) directly (149). Ring-finger containing E3 ligase MDM2 (150) ubiquitinylates androgen receptor, leading to its degradation. Increase of androgen receptor expression promoted expression of FK506 binding protein 5 (FKBP5) and PHLPP, resulting in inactivation of p-AKT $(149,151)$ and concomitant inhibition of metastases. $m i R-379$ is significantly down-regulated in patients with HCC and inhibits HCC cell line migration in vitro and metastasis in vivo (152). FAK has been identified as a direct target of $m i R-379$ (152). Repression of FAK leads to inhibition of AKT signaling (152). FAK has been identified as a mediator of metastasis of HCC (153).

$m i R-422$ is down-regulated in HCC samples and cell lines and inhibited proliferation and migration of HCC cell lines HCCLM3, MHCC97-H and SMMC-7721 (154). Forkhead box transcription factors FOXG1, FOXQ1 and FOXE1 were identified as direct targets of $m i R-422$ (154). FOXG1 plays a critical role in HCC pathogenesis and metastasis (155). HCCLM3 and MHCC97-H cells transfected with an expression vector for $m i R-422$ gave rise to reduced numbers of hepatic metastases after subcutaneous implantation into immuno-deficient mice in comparison to a corresponding control cell line (154).

Down-regulation of $m i R-503$ (Figure 4C) correlates with increased metastatic potential of HCC cell lines and clinical HCC (156). Subcutaneous implantation of HCCLM3 cells transfected with an expression vector for $m i R-503$ reduced tumor growth and lung metastases in comparison to a corresponding control cell line (156). Brefeldin-inhibited guanine nucleotide exchange factor protein 1 (ARHGEF19), was identified as a direct target of $m i R-503$ (156). ARHGEF19 catalyzes the release of GDP on small GTPases in exchange for GTP and results in their activation (157). Small GTPases play an important role in metastasis of HCC (158).

Expression of $m i R-885-5 \mathrm{p}$ suppressed migration of HCCLM3, SK-Hep1 and HepG2 cells (159). In vivo, in an orthotopic HCCM3-miR-885-5p model, number and size of nodules in the lungs are reduced in comparison to corresponding controls (159). $\beta$-Catenin was identified as a direct target of $m i R-885-5 p$ (159). The WNT signaling pathway plays an important role in pathogenesis and metastasis of HCC (160). Down-regulation of $m i R-885-5 \mathrm{p}$ correlates with poor survival in patients with $\mathrm{HCC}$ and $m i R-885-5 \mathrm{p}$ expression is inversely correlated with expression of $\beta$-catenin (159).

miRs interfering with EMT. miR-139-3p is down-regulated in HCC and inhibits growth after subcutaneous implantation and formation of pulmonary metastatic foci after tail vein injection of HepG2 cells transfected with miR-139-3p in immunodeficient mice (161). miR-139-3p targets the annexin A2 receptor (ANXA2R) which is involved in EMT, regulation of adhesion, migration, growth and homing of tumor cells (162). $m i R-139-3 p$ expression is inversely correlated with ANXA2R expression in human HCC tissues (161).

$m i R-148 a$ inhibits migration of several HCC cell lines in a transwell assay and represses pulmonary metastases in an orthotopic xenograft model (163). Receptor tyrosine kinase c-MET was identified as a direct target of miR-148a (163). Inhibition of c-MET attenuates AKT signaling and reduces nuclear accumulation of SNAIL, a transcription factor promoting EMT $(163,164)$. Expression of $m i R-148 a$ is significantly reduced in HCC tissues in comparison to normal liver-related tissues (163).

miR-187-3p is down-regulated in patients with HCC in comparison to normal liver tissue and inhibits invasion of $\mathrm{HCC}$ cells in vitro and metastasis in vivo in mice. Hypoxic conditions are responsible for the reduced levels of $m i R-187-3 \mathrm{p}$ in HCC (165). S100 calcium binding protein 4 (S100A4), the direct target of $m i R-187-3 p$, promotes metastasis via EMT (166). Down-regulation of $m i R-187-3 \mathrm{p}$ correlates with adverse clinical features and poor prognosis of patients with HCC (165).

miR-192 is down-regulated in metastatic HCC cell lines and patients and inhibited migration and invasion of HCC-LM3, Huh7 and SK-Hep-1 HCC cells (167). In an orthotopic xenograft model, Huh7 cells transfected with $m i R-192$ gave rise to fewer intrahepatic metastases in comparison to control cells (167). Solute carrier 39A6 (SLC39A6) was identified as a direct target of miR-192 (167). SLC39A6 is a transmembrane zinc transporter that regulates invasion of several types of cancer $(168,169)$.

miR-200a functions in HCC cells enriched in CSC-like activity and CSC-related phenotype, referred to as side population cells (170). miR-200a inhibits invasion and migration of side population cells derived from MHCC-97H and Huh7 HCC cells (170). Up-regulation of miR-200a in side population cells reduced the number of lung metastatic nodules after injection into the caudal vein of mice and increased their overall survival time (170). Transcription factor zinc finger E-box binding 2 (ZEB2) was identified as 
a direct target of miR-200a (170). ZEB2 together with SNAIL, AKT and FOX are drivers of EMT, which is associated with expression of mesenchymal markers $(\mathrm{N}$ cadherin, vimentin) and repression of epithelial markers (CDH1 and zona occludens protein 1) $(171,172)$.

Liver regeneration and hepatectomy has been reported to be involved in recurrence and metastasis of a residual HCC (173). In a rat model, HCC was initiated by administration of diethylnitrosamine and CCL4 (174). A recombinant adenovirus expressing $m i R-203$ injected after $30 \%$ hepatectomy inhibited residual HCC invasion and lung metastases (174). miR-203 down-regulates EMT mediator IL1 $\beta$, SNAIL and TWIST (174). Independent work has shown that $m i R$-203 directly targets SNAIL, ZEB and TWIST transcription factors in nasopharyngeal carcinoma (174).

Ectopic expression of miR-449a suppressed invasion and HCC cell colony formation in vitro of Hep3B, Bel-7402, SMCC-7721, MHCC-LM9, Huh7 and HepG2 cells (175). Restoration of miR-449 expression in Huh7 cells inhibitand lung metastases after intrahepatic implantation (175). FOS and c-MET were identified as direct targets of $m i R-449 a$ (175). FOS and c-MET are overexpressed in HCC and are able to induce EMT $(176,177)$.

$m i R-501-3 \mathrm{p}$ inhibits migration, proliferation and EMT of HCCLM3 and PLC/PRF/5 HCC cells as shown by gain and loss of function experiments (178). The incidence of lung metastasis of HCCLM3 transfected with $m i R-501-3$ p cells was reduced in comparison to control cells in an orthotopic mouse model (178). LIN7A homolog A (LIN7A) was identified as a target of $m i R-501-3 \mathrm{p}$ (178). It was shown that LIN7A mediates the effects of miR-501-3p in vivo (178). LIN7A is a member of the crumbs-complex polarity genes and polarity deficiency has been identified as an essential step of EMT progression and a hallmark of tumor invasion and metastasis (179).

miR-630 (Figure 4C) inhibited migration and EMT in HCC cell lines Bel7402 and HLF (180). miR-630 had no effect on tumor growth of Bel7402 cells after subcutaneous implantation, but its inhibition in Bel7402 cells increased metastatic foci in an orthotopic mouse model (180). miR-630 is repressed by TGF $\beta$ and directly targets SLUG, a nuclear transcription factor which increases transcription of $\mathrm{CDH} 1$ mRNA by binding to the E-box element of the $C D H 1$ promoter (181). Decreased miR-630 expression is associated with metastasis and poor clinical outcome (181).

miR-1271 inhibits HCC migration, invasion, EMT and the formation of lung metastases (182). $m i R-1271$ targets protein tyrosine phosphatase 4A member 1 (PTP4A1) which inactivates SRC, a tyrosine kinase which promotes metastasis (183). miR 1271 down-regulation correlates with HCC progression (182).

miR-1296 inhibited cell migration, invasion and EMT of HCC cell lines HCCLM3 and Hep3B (184). HCCLM3 cells transfected with $m i R-1296$ gave rise to fewer and smaller foci in the lungs of nude mice after injection into the lateral vein in comparison to control cells (184). Serine/threonineprotein kinase (SRPK1) was identified as a direct target of miR-1296 (184). SRPK1 can activate PI3K/AKT which is crucial for EMT of HCC (185).

miRs inhibiting additional targets. miR-30a acts as an inhibitor of autophagy during starvation in HCC cell lines and attenuates anoikis resistance (186). $m i R-30 a$ reduced lung metastasis of HCCLM3 cells in nude mice after tail vein injection (186). Pro-autophagic proteins beclin 1 and autophagy-related 5 (ATG5) were identified as direct targets of miR-30a (186). Autophagy plays a role in HCC metastasis through facilitating anoikis resistance and colonization of HCC cells (187). In addition, miR-30a inhibited microvascular invasion and recurrence in HCC tissue samples (186).

miR-122 inhibits in vivo growth and metastasis of Mahlavu cells after intrahepatic administration, partly based on inhibition of angiogenesis (188). A disintegrin and metalloproteinase 17 (ADAM17) has been identified as a critical downstream target (188). ADAM17 facilitates activation of tumor necrosis factor $\alpha(\mathrm{TNF} \alpha)$ and epidermal growth factor receptor (EGFR) ligand TGF $\alpha$, modulates integrin signaling during cell adhesion, and is associated with endothelial cells (189-192).

$m i R-382$ is down-regulated in HCC cell lines and tissues (193). $m i R-382$ suppresses migration and invasion of Huh7 and HepG2 cells and inhibits lung metastasis of these cells after tail vein injection (193). No effect on proliferation, apoptosis and cell-cycle-related parameters has been observed in HCC cell lines (193). Golgi membrane protein 1 (GOLM1) was identified as a direct target of $m i R-382$ (193). GOLM1 has been shown to be involved in EGFR recycling and metastasis in HCC (194).

\section{Therapeutic Aspects}

We have summarized metastasis-promoting and -inhibiting miRs as modulators of HCC-related metastasis, focusing on those with documented efficacy in metastasis-related in vivo models. They can be grouped into different functional categories such as tumor-suppressor gene-, angiogenesis-, cellcycle-, cytoskeleton-, signaling-, EMT- and glycosylationrelated. For further ranking with respect to potential as therapeutic targets, correlation between expression in patients with HCC and corresponding prognostic value is important to differentiate/prioritize miRNA as target candidates. Based on criteria as outlined we have identified six metastasis-promoting miRs: $m i R-29 \mathrm{a}, m i R-219-5 \mathrm{p}, m i R-331-3 \mathrm{p}, m i R-425-5 \mathrm{p}, m i R-$ 487a and miR-1247-3p (Figure 2), and six metastasis-inhibiting miRs: $m i R-101, m i R-129-3 p, m i R-137, m i R-149$, miR-503, $m i R-630$ ) (Figure 4A and B) as potential therapeutic targets to address HCC-related metastasis. For those, in vivo efficacy was evaluated in metastasis-related mouse xenograft models 
making use of orthotopic implantation $(n=6)$, subcutaneous implantation $(n=2)$, intrasplenic implantation $(n=1)$ or tail vein injection $(n=3)$. We did not prioritize miRs with deregulated expression in $\mathrm{HCC}$ in comparison to corresponding tissues but instead pending correlation with respect to patients' outcomes. Considering that orthotopic implantation may most closely simulate HCC-related metastasis, metastasis-promoting $m i R$ 29a, $m i R-219-5 \mathrm{p}, m i R-425-5 \mathrm{p}$ and $m i R-487 \mathrm{a}$, and metastasisinhibiting $m i R-129-3 \mathrm{p}$ and $m i R-630$ may represent potential therapeutic targets. However, the currently available data do not permit an assignment of these miRs to defined molecular and immunological subtypes of HCC.

Depending on the type of deregulation of the target miRs, the therapeutic options are either inhibition or reconstitution their function. miR antagonists (antagomirs) are single-stranded antisense oligonucleotides (ASOs) which anneal to the mature miR guide strand and induce its degradation or formation of stoichiometric inhibitory duplex. Antagomirs are the most popular miR inhibitors because all optimizations achieved for ASOs can be incorporated into the design of antagomirs (16, 196-198). Another option for inhibition of miRs are miR sponges which contain in-tandem multiple complementary binding sites for the target miR. They are expressed in target cells by corresponding vectors $(16,195,196)$.

Therapeutic application of nucleic acid-based entities and small molecule inhibitors of miRs are an emerging field (197). Specificity issues inherent to the latter approach might be circumvented by targeting unique secondary structures. There are two options for replenishment of down-regulated miRs. One option is the design of miR mimetics, synthetically derived RNA duplexes which mimic the function of the corresponding miR. The other option is reconstitution of $\mathrm{miR}$ function by inserting miRs into viral vectors and express them in corresponding target cells (198). Since miRs regulate a large set of genes, inhibition or reconstitution of their function has the potential of restoring coordinated functionality. On the other hand, there are many issues which have to be resolved regarding application (and optimization) of miRs and miRtargeting entities as therapeutic agents. Among these are toxicity-related issues due to nonspecific hybridization with non-target miRs, targeting of healthy tissues, case-by-case optimization of pharmaco-kinetic and pharmaco-dynamic properties, degradation by nucleases, elimination by the reticulo-endothelial system, kidney filtration, immunogenicity, sequestration into endosomes and fundamental issues of their delivery to cancer tissues (199-205).

Efforts to enhance properties of nucleic acid-based therapeutics have led to multiple chemical modifications in the sugar, base and backbone of RNA nucleotides. These modifications have mainly focused on increasing the affinity to the target RNA sequence, improving the pharmacokinetic properties and reducing immunogenicity. The most widely applied nucleotide modification for ASOs has been the replacement of the phosphodiester backbone with a phosphorothioate linkage. This modification dramatically increases nuclease resistance and ASO binding to serum albumin, which leads to a much improved pharmacokinetic profile and distribution to most peripheral tissues, with distinct accumulation in liver and kidney (206-208).

Besides albumin, phosphorothioate-modified ASOs also bind to extracellular, cell membrane and intracellular proteins, which facilitates their entry into cells and intracellular trafficking. Upon adsorption to membrane proteins, ASOs internalize into cells through multiple pathways, which can lead to 'productive' uptake and antisense effects intracellularly or the ASOs become routed and trapped in 'non-productive' cellular compartments. Although the requirements for productive intracellular trafficking have not been fully identified and antisense efficacy varies greatly between ASOs as well as cell types and their activation status, phosphorothioate-modified ASOs can reach the cytoplasm and nucleus. Achieving antisense efficacy without the need of an additional delivery agent represent a major advantage to previous nucleic acid-based therapeutics (209-211).

Recently, quantitative fluorescence imaging revealed that locked nucleic acid-modified ASOs traffick to the nucleus within minutes upon injection directly into the cytoplasm. Approximately $10^{5}$ ASOs are required for $50 \%$ target knock down, suggesting that a large proportion remains bound to nuclear components and is not available for RNase H1mediated degradation of the target RNA (212).

Considering this high number of required ASOs, current research is focused on the improvement of their intracellular delivery. Uptake of nucleic acid-based therapeutics into cells can be enhanced by various means. For example, making use of polymers such as high molecular weight polyethyleneimine (PEI) and encapsulation in lipid-based nanoparticles with a positive charge enabling binding to the negatively charged cell surface has improved delivery (204). Stabilization of the delivery vehicles or of the therapeutic agents with polyethylene glycol is also an important improvement (213). Liver specific delivery can be achieved by conjugation of PEI with galactosamine which interacts with asialoprotein receptors on hepatocytes and leads to internalization of the complexes by receptor-mediated endocytosis $(203,204)$. Further options for hepatocyte-specific delivery are outlined elsewhere $(203,204)$. Even local administration of miRs into the liver may be an option. Advantageous characteristics of a potential miR-related target under consideration would be simultaneous inhibition of proliferation, migration, invasion and intrahepatic metastasis. Eradication of local and distant metastases by the corresponding miR-related therapeutic agent as a single agent or in combination with other agents should be the ultimate goal of anti-metastatic therapy. Unfortunately, the described preclinical models do not include models which allow targeting of established metastases. Preventive scenarios do not seem to 
be realistic due the necessity of continued application and resulting possible toxicity-related issues.

The field of miR-related agents has witnessed several severe drawbacks in the recent past (214). Clinical studies of Regula Therapeutics with $m i R-17$ and $m i R-21$ inhibitors for treatment of inherited polycystic kidney disease and Alpert syndrome were paused due to toxicity issues (214).

In 2016, clinical evaluation of a miR-122 inhibitor for treatment of $\mathrm{HCV}$ infections was put on hold due to jaundice in patients caused by inhibition of a bile duct transporter, despite an excellent efficacy profile (214). Also, in 2016, a clinical study of a synthetic mimic of miR-34 (miRNA Therapeutics) for treatment of multiple types of cancer was halted in phase I due to severe side-effects (214). On the other hand, miRagen is pursuing clinical studies with MRG106 (cobomersen), a gapmer, in patients with leukemias and lymphomas without any adverse effects observed during phase I (214). It remains to be seen whether secondgeneration molecules with an improved toxicity profile will emerge as game changers in this field.

\section{Conflicts of Interest}

FB, DS and UB are employees of Roche, UHW was an employee of Roche.

\section{Authors' Contributions}

DS, UB and UHW wrote the article, FB prepared the Figures and performed the bioinformatics analysis.

\section{References}

1 Llovet JM, Zucmann-Rossi J, Pikarsky E, Sangro B, Schwartz M, Sherman M and Gores G: Hepatocellular carcinoma. Nat Rev Dis Primers 2: 16018, 2016. PMID: 27158749. DOI: 10.1038/ nrdp.2016.18

2 Arzumanyan A, Reis HM and Feitelson MA: Pathogenic mechanisms in HBV- and HCV-associated hepatocellular carcinoma. Nat Rev Cancer 13: 123-135, 2013. PMID: 23344543. DOI: $10.1038 / \mathrm{nrc} 3449$

3 Knox JJ, Cleary SP and Dawson LA: Localized and systemic approaches to treating hepatocellular carcinoma. J Clin Oncol 33: 1835-1844, 2015. PMID: 25918289. DOI: 10.1200/JCO. 2014.60.1153

4 Llovet JM, Montal R, Sia D and Finn RS: Molecular therapies and precision medicine for hepatocellular carcinoma. Nat Rev Clin Oncol 15: 599-616, 2018. PMID: 30061739. DOI: 10.1038/s41571-018-0073-4

5 Dawkins J and Webster RM: The hepatocellular market. Nat Rev Drug Discov 18: 13-14, 2019. PMID: 30168534. DOI: 10.1038/nrd.2018.146

6 Hoshida Y, Nijman SM, Kobayashi M, Chan JA, Brunet JP, Chiang DY, Villanueva A, Newell P, Ikeda K, Hashimoto M, Watanabe G, Gabriel S, Friedman SL, Kumeda H, Llovet JM and Golub TR: Integrative transcriptome analysis reveals common molecular subclasses of human hepatocellular carcinoma. Cancer
Res 69: 7385-7392, 2009. PMID: 19723656. DOI: 10.1158/00085472.CAN-09-1089

7 Lee YT and Geer DA: Primary liver cancer: patterns of metastasis. J Surg Oncol 36: 26-31, 1987. PMID: 3041113.

8 Li Q, Wang J, Juzi JT, Sun Y, Zheng H, Cui Y, Li H and Hao X: Clonality analysis for multicentric origin and intrahepatic metastasis in recurrent and primary hepatocellular carcinoma. $\mathrm{J}$ Gastrointest Surg 12: 1540-1547, 2008. PMID: 18629593. DOI: 10.1007/s11605-008-0591-y

9 Yang SL, Luo YY, Chen M, Zhou YP, Lu FR, Deng DF and Wu YR: A systematic review and meta-analysis comparing the prognosis of multicentric occurence and vs intrahepatic metastasis in patients with recurrent hepatocellular carcinoma after hepatectomy. HPB 19: 835-842, 2017. PMID: 28734693. DOI: 10.1016/j.hpb.2017.06.002

10 Becker AK, Tso DK, Harris AC, Malfair D and Chang SD: Extrahepatic metastases of hepatocellular carcinoma: A spectrum of imaging findings. Can Assoc Radiol 65: 60-66, 2014. PMID: 24239313. DOI: 10.1016/j.carj.2013.05.004

11 Katval S, Oliver JH 3rd, Petersen MS, Ferris JV, Carr BS and Baron JL: Extrahepatic metastases of hepatocellular carcinoma. Radiology 216: 698-703, 2000. PMID: 1096669 DOI:10.1148/ radiology.216.3.r00se24698

12 Grandhi MS, Kim AK, Ronnekleiv-Kelly SM, Kamel IR, Ghasebeh MA and Pawlik TM: Hepatocellular carcinoma: From diagnosis to treatment. Surg Oncol 25: 74-85, 2016. PMID: 27312032 DOI: 10.1016/j.suronc.2016.03.002

13 Zhu AX, Duda DG, Sahani DV and Jain RK: HCC and angiogenesis: possible targets and furture directions. Nat Rev Clin Oncol 8: 292-301, 2011. PMID: 21386818. DOI: 10.1038/ nrclinonc. 2011.30

14 Liaw CC, Ng KT, Chen TJ and Liaw YF: Hepatocellular carcinoma presenting as bone metastasis. Cancer 64: 1753-1757, 1989. PMID: 2477134.

15 Bartel DP: Metazoan MicroRNAs. Cell 173: 20-51, 2018. PMID: 29570994. DOI: 10.1016/j.cell.2018.03.006

16 Rupaimoole R and Slack FJ: MicroRNA therapeutics: towards a new era for the management of cancer and other diseases. Nat Rev Drug Discov 16: 203-222, 2017. PMID: 28209991. DOI: 10.1038/nrd.2016.246

17 Pillai RS: MicroRNA function: multiple mechansisms for a tiny RNA? RNA 11: 1753-1761, 2005. PMID: 16314451. DOI: 10.1261/rna.2248605

18 Bentwich I, Avniel A, Karov Y, Aharonov R, Gilad S, Barad O, Birzilai A, Einat P, Einav U, Meiri F, Sharon E, Spector Y and Bentwich Z: Identification of conserved and nonconserved microRNAs. Nat Genet 37: 766-770, 2005. PMID: 15965474. DOI: $10.1038 / \mathrm{ng} 1590$

19 Bartel DP: MicroRNAs: genomics, biogenesis, mechanism, and function. Cell 116: 281-298, 2004. PMID: 14744438. DOI: 10.1016/S0092-8674(04 00045-5

20 Reddy KB: MicroRNA (miRNA) in cancer. Cancer Cell Int 15: 38, 2015. PMID: 25960691. DOI: 10.1186/s12935-015-0185-1

21 Peter ME: Targeting of mRNAs by multiple miRNAs: the next step. Oncogene 29: 2161-2164, 2010. PMID: 20190803. DOI: 10.1038/onc.2010.59

22 Cimmino A, Calin GA, Fabbri M, Iorio MV, Ferracin M, Shimizu M, Wojcik SE, Ageilan RI, Zupo S, Dono M, Rassenti L, Alder $\mathrm{H}$, Volinia S, Liu CG, Kipps TJ, Negroni M and Croce CM: $m i R$ 15 and $m i R-16$ induce apoptosis by targeting BCL2. Proc Natl 
Acad Sci USA 102: 13944-13949, 2005. PMID: 16166262. DOI: 10.1073/pnas.0506654102

23 Calin GA, Cimmino A, Fabbri M, Ferracin M, Wojcik SE, Shimizu M, Taccioli C, Zanesi N, Garzon R, Aqeilan RI, Alder H, Volinia S, Rassenti L, Liu X, Liu CG, Kipps TJ, Negrini M and Croce CM: $m i R-15 a$ and $m i R-16-1$ cluster functions in human leukemia. Proc Natl Acad Sci USA 105: 5166-5171, 2008. PMID: 18362358. DOI: $10.1073 /$ pnas.0800121105

24 Weidle UH, Dickopf S, Hintermair C, Kollmorgen G, Birzele F and Brinkmann U: The role of micro RNAs in breast cancer metastasis: preclinical validation and potential therapeutic targets. Cancer Genomics Proteomics 15: 17-39, 2018. PMID: 29275360. DOI: $10.21873 / \operatorname{cgp} .20062$

25 Weidle UH, Birzele F, Kollmorgen G and Nopora A: Potential micro-RNA-related targets for therapeutic intervention with ovarian cancer metastasis. Cancer Genomics Proteomics 15: 115, 2018. PMID: 29275359. DOI: $10.21873 /$ cgp. 20061

26 Tokkarz P and Blasiak J: The role of microRNA in metastatic colorectal cancer and its significance in cancer prognosis and treatment. Acta Biochem Pol 59: 467-474, 2012. PMID: 23173124.

27 Pencheva N and Tavazoie SG: Control of metastatic progression by microRNA regulatory networks. Nat Cell Biol 15: 546-554, 2013. PMID: 23728460. DOI: 10.1038/ncb2769

28 Newell P, Villanueva A and Llovet JM: Molecular targeted therapies in hepatocellular carcinoma: from preclinical models to clinical trials. J Hepatol 49: 1-5, 2008. PMID: 18486262. DOI: 10.1016/j.jhep.2008.04.006

29 He L, Tian DA, Li PY and He XX: Mouse models of liver cancer: progress and recommendations. Oncotarget 6: 23306-23322, 2015. PMID: 26259234. DOI: $10.18632 /$ oncotarget.4202

30 Shearn CT and Petersen DR: Understanding the tumor suppressor PTEN in chronic alcoholism and hepatocellular carcinoma. Adv Ex Biol Med 815: 173-184, 2015. PMID: 25427907. DOI: 10.1007/978-3-319-09614-8_10

31 Song MS, Salmena L and Pandolfi PP: The functions and regulation of the PTEN tumor suppressor. Nat Rev Mol Cell Biol 13: 283-296, 2012. PMID: 22473468. DOI: 10.1038/nrm3330

32 Chang RM, Xu JF, Fang F, Yang H and Yang LY: MicroRNA$130 \mathrm{~b}$ promotes proliferation and EMT-induced metastases via PTEN/p-AKT/HIF1 $\alpha$ signaling. Tumor Biol 37: 10609-10619, 2016 PMID: 26861561. DOI: 10.1007/s13277-016-4919-Z

33 Fang F, Song T, Zhang T, Cui Y, Zhang G and Xiong Q: MiR425-5p promotes invasion and metastasis of hepatocellular carcinoma cells through SCAI-mediated dysregulation of multiple signaling pathways. Oncotarget 8: 31745-31757, 2017. PMID: 26861561. DOI: $10.1007 / \mathrm{s} 13277-016-4919-\mathrm{z}$

34 Brandt DT, Baarlink C, Kitzing TM, Kremmer E, Ivaska J, Nollau $\mathrm{P}$ and Grosse R: SCAI acts as a suppressor of cancer cell invasion through the transcriptional control of beta1 integrin. Nat Cell Biol 11: 557-568, 2009. PMID: 19350017. DOI: $10.1038 / \mathrm{ncb} 1862$

35 Tang J, Li L, Huang W, Sui C, Yang Y, Lin X, Hou G, Chen X, Fu J, Yuan S, Li S, Wen W, Tang S, Cao D, Wu M, Chen L and Wang H: MiR-429 increases the metastatic capability of HCC via regulating classic Wnt pathway rather than epithelialmesenchymal transition. Cancer Lett 364: 33-43, 2015. PMID: 25931210. DOI: 10.1016/j.canlet.2015.04.023

36 Liu S, Guo W, Shi J, Lin N, Yu X, Xue J, Fu X, Chu K, Lu C, Zhao J, Xie D, Wu M, Cheng S and Liu S: Micro RNA-135a contributes to the development of portal vein thrombus by promoting metastasis in hepatocellular carcinoma. J Hepatol 56: 389-396, 2012. PMID: 21888875. DOI: 10.1016/j.jhep.2011. 08.008

37 Ma S, Guan XY, Lee TK and Chan KW: Clinicopathological significance of missing in metastasis $\mathrm{B}$ expression in hepatocellular carcinoma. Human Pathol 38: 1201-1206, 2007. PMID: 21888875. DOI: 10.1016/j.jhep.2011.08.008

38 Ghaleb AM and Yang VW: Krüppel-like factor 4 (KLF4): What we currently now. Gene 611: 27-37, 2017. PMID: 28237823. DOI: 10.1016/j.gene.2017.02.025

39 Lin ZS, Chu HC, Yen YC, Lewis BC and Chen YW: Krüppel-like factor 4, a tumor suppressor in hepatocellular carcinoma reverts epithelial mesenchymal transition by suppressing SLUG expression. PLoS One 7: e43593, 2012. PMID: 22937066. DOI: 10.1371/journal.pone.0043593

40 Yao S, Tian C, Ding Y, Ye Q, Gao Y, Yang N and Li Q: Downregulation of Krüppel-like factor 4 by microRNA-135a-5p promotes proliferation and metastasis in hepatocellular carcinoma by transforming growth factor $\beta 1$. Oncotarget 7: 42566-42578, 2016. PMID: 27302923. DOI: 10.18632/oncotarget.9934

$41 \mathrm{NiF}$, Zhao H, Cui H, Wu Z, Chen 1, Hu Z, Guo C, Liu Y, Chen Z, Wang X, Chen D, Wie H and Wang S: MicroRNA-362-5p promotes tumor growth and metastasis by targeting CYLD in hepatocellular carcinoma. Cancer Lett 356: 809-818, 2015. PMID: 22937066. DOI: 10.1371/journal.pone.0043593

42 Hellerbund $\mathrm{C}$ and Massoumi R: Cylindromatosus - a protective molecule against liver diseases. Med Res Rev 36: 342-359, 2016. PMID: 26763122. DOI: 10.1002/med.21381

43 Mathis BJ, Lai Y, Qu C, Janicke JS and Cui T: CYLD-mediated signaling and diseases. Curr Drug Targets 16: 284-294, 2015. PMID: 25342597.

44 Du J, Bai F, Zhao P, Li X, Gao L, Ma C and Liang X: Hepatitis B core protein promotes liver cancer metastasis through $m i R$-3825p/DLC-1 axis. Biochim Biophys Acta Mol Cell Res 1865: 1-11, 2018. PMID: 28982593. DOI: 10.1016/j.bbamcr.2017.09.020

45 Lahoz A and Hall A: DLC1: A significant GAP in the cancer genome. Genes Dev 22: 1724-1739, 2008. PMID: 18593873. DOI: $10.1101 / \mathrm{gad} .1691408$

46 Kim TY, Vigil D, Der CJ and Juliano RL: Role of DLC-1, a tumor suppressor protein with RhoGAP activity, in regulation of the cytoskeleton and cell motility. Cancer Metastasis Res 28: 7783, 2009. PMID: 19221866. DOI: 10.1007/s 10555-008-9167-2

47 Shih YT, Wang MC, Zhou J, Peng HH, Lee Dy and Chiu JJ: Endothelial progenitors promote hepatocarcinoma intrahepatic metastasis through monocyte chemotactic protein-1 induction of microRNA-21. Gut 64: 1132-1147, 2015. PMID: 24939570. DOI: 10.1136/gutjnl-2013-306302

48 Dagouassat M, Suffee N, Hlawaty H, Haddad O, Charni F, Laquillier C, Vassy R, Martin L, Schischmanoff PO, Gattegno L, Oudar O, Sutton A and Charnaux N: Monocyte chemoattractant protein-1 (MCP-1/CCL2) secreted by hepatic myofiboblasts promotes migration and invasion of human hepatoma cells. Int $\mathrm{J}$ Cancer 126: 1095-1108, 2010. PMID: 19642141. DOI: $10.1002 / \mathrm{ijc} .24800$

49 Nicoloso MS, Spizzo R, Shimizu M, Rossi G and Calin GA: MicroRNAs - the micro steering wheel of tumor metastasis. Nat Rev Cancer 9: 293-302, 2009. PMID: 19262572. DOI: $10.1038 / \mathrm{nrc} 2619$

50 Akilesh S, Suleiman H, Stander MC, Lavin P, Gbadegesin R, Antignac C, Pollak M, Kopp JB, Winn MP and Shaw AS: 
Arhgap24 inactivates Rac1 in mouse podocytes, and a mutant form is associated with familial focal segmental glomerulosclerosis. J Clin Invest 121: 4127-4137, 2011. PMID: 21911940. DOI: 10.1172/JCI46458

51 Jackson HW, Defamie V, Waterhouse P and Khokha R: TIMPs: Versatile extracellular regulators in cancer. Nat Rev Cancer 17: 38-53, 2017. PMID: 27932800. DOI: 10.1038/nrc.2016.115

52 Chen Q, Yin D, Zhang Y, Lu L, Li XD, Zhou ZJ, Zou Sl, Gao DM, Hu J, Jin C, Wang Z, Shi YH, Cao Y, Fan J, Dai Z and Zhou $\mathrm{J}$ : MicroRNA-29a induces loss of 5-hydroxymethylcytosine and promotes metastasis of hepatocellular carcinoma through a TETSOCS1-MMP9 signaling axis. Cell Death Dis 8: e2906, 2017. PMID: 28661477. DOI: $10.1038 /$ cddis.2017.142

53 Yoshikawa H, Matsubara K, Qian GS, Jackson P, Groopman JD, Manning JE, Harris CC and Herman JG: SOCS-1, a negative regulator oft he JAK/STAT pathway, is silenced by methylation in human hepatocellular carcinoma and shows growth-suppression activity. Nat Genet 28: 29-35, 2001. PMID: 11326271. DOI: $10.1038 / 88225$

54 Tahiliani M, Koh KP, Shen Y, Pastor WA, Bandukwala H, Brudno Y, Agarwal S, Iver LM, Liu LM, Liu DR, Aravind L and Rao A: Conversion of 5-methycytosine to 5-hydroxymethylcytosine in mammalian DNA by MLL partner TET1. Science 324: 930-935, 2009. PMID: 19372391. DOI: 10.1126/ science. 1170116

55 Li Y, Xu D, Bao C, Zhang Y, Chen D, Zhao F, Ding J, Liang L, Wang Q, Liu L, Li J, Yao M, Huang S and He X: MicroRNA135b, a HSF1 target, promotes tumor invasion and metastasis by regulating RECK and EVI5 in hepatocellular carcinoma. Oncotarget 6: 2421-2433, 2015. PMID: 25537516. DOI: $10.18632 /$ oncotarget. 2965

56 Oh J, Takahashi R, Kondo S, Mizoguchi A, Adachi E, Sasahara RM, Nishimura S, Imamura Y, Kitayama H, Alexander DB, Die C, Horan TP, Arakawa T, Yoshida H, Nishikawa S, Itoh Y, Seiki M, Itohara S, Takahashi C and Noda M: The membrane anchored MMP inhibitor RECK is a key regulator of extracellular matrix integrity and angiogenesis. Cell 107: 789-800, 2001. PMID: 11747814. DOI: 10.1016/S0092-8674/01 00597-9

57 Lim YS and Tang BL: The Evi5 family in cellular physiology and pathology. FEBS Lett 587: 1703-1710, 2013. PMID: 23669355. DOI: 10.1016/j.febslet.2013.04.036

58 Yan-Chun L, Hong-Mei Y, Zhi-Hong C, Qing H, Yan-Hong Z and Ji-Fang W: MicroRNA-192-5p promote the proliferation and metastasis of hepatocellular carcinoma by targeting SEMA3A. Appl Immunohistochem Mol Morph 25: 251-260, 2017. PMID: 26580097. DOI: 10.1097/PAI.0000000000000296

59 Neufeld G, Shraga-Heled N, Lange T, Guttmann-Raviv N, Herzog $\mathrm{Y}$ and Kessler O: Semaphorins in cancer. Fronst Biosc 10: 751760, 2005. PMID: 15569615. DOI: 10.2741/1569

60 Chang RM, Yang H, Fang F, Xu JF and Yang LY: MicroRNA331-3p promotes proliferation and metastasis of hepatocellular carcinoma by targeting $\mathrm{PH}$ domain and leucine-rich repeat protein phosphatase. Hepatology 60: 1251-1263, 2014. PMID: 24825302. DOI: $10.1002 /$ hep. 27221

61 Nitsche C, Edderkaoui M, Moore RM, Eible G, Kasahara N, Treger J, Grippo PJ, Mayerle J, Lerch MM and Gukovskaya AS: The phosphatase PHLPP1 regulates Akt2, promotes pancreatic cancer cell death and inhibits tumor formation. Gastroenterology 142: 377-387, 2012. PMID: 22044669. DOI: $10.1053 /$ j.gastro.2011.10.026
62 Chang RM, Xiao S, Lei X, Yang H, Fang F and Yang LY: miRNA-487a promotes proliferation and metastasis in hepatocellular carcinoma. Clin Cancer Res 23: 2593-2604, 2017. PMID: 27827315. DOI: 10.1158/1078-0432.CCR-16-0851

63 Kachroo N, Valencia T, Warren AY and Gnanapragasam VJ: Evidence for downregulation of the negative regulator SPRED2 in clinical prostate cancer. Br J Cancer 108: 597-601, 2013. PMID: 23169297. DOI: 10.1038/bjc.2012.507

64 Yoshida T, Hisamoto T, Akiba J, Koga H, Nakamura K, Tokunaga Y, Hanada S, Kumemura H, Maeyama M, Harada M, Ogata H, Yano H, Kojiro M, Ueno T, Yoshimura A and Sata M: Spreds, inhibitors of the Ras/ERK signal transduction, are dysregulated in human hepatocellular carcinoma and linked to the malignant phenotype of tumors. Oncogene 25: 6056-6066, 2006. PMID: 16652141. DOI: 10.1038/sj.onc.1209635

65 Taniguchi CM, Winnay J, Kondo T, Bronson RT, Guimaraes AR, Aleman JO, Luo J, Stephanopoulos G, Weissleder R, Cantley LC and Kahn CR: The phosphoinosite 3-kinase regulatory subunit p85alpha can exert tumor suppressor properties through negative regulation of growth factor signaling. Cancer Res 70: 5305-5315, 2010. PMID: 16652141. DOI: 10.1038/sj.onc.1209635

66 Chagpar RB, Links PH, Pastor MC, Furber LA, Hawrysch AD, Chamberlain MD and Anderson DH: Direct positive regulation of PTEN by the p85 subunit of phosphatidyinositol 3-kinase. Proc Natl Acad Sci USA 107: 5471-5476, 2010. PMID: 20212113. DOI: $10.1073 /$ pnas.0908899107

67 Fang JH, Zhang ZJ, Shang LR, Luo YW, Lin YF and Zhuang SM: Hepatoma cell-secreted exosomal microRNA-103 increases vascular permeability and promotes metastasis by targeting junction proteins. Hepatology 68: 1459-1475, 2018. PMID: 29637568. DOI: $10.1002 /$ hep. 29920

68 Bazzoni G and Dejana E: Endothelial cell-to-cell junctions: molecular organization and role in vascular homeostasis. Physiol Rev 84: 869-901, 2004. PMID: 15269339. DOI: 10.1152/ physrev.00035.2003

69 Ishiyama N, Lee SH, Liu S, Li GY, Smith MJ, Reichardt LF and Ikura M: Dynamic and static interactions between p120 catenin and E-cadherin regulate the stability of cell-cell adhesion. Cell 141: 117-128, 2010. PMID: 20371349. DOI: 10.1016/j.cell.2010. 01.017

70 Zhang X, Liu S, Hu T, Liu S, He Y and Sun S: Up-regulated microRNA-143 transcribed by nuclear factor kappa B enhances hepatocarcinoma metastasis by repressing fibronectin expression. Hepatology 50: 490-499, 2009. PMID: 19472311. DOI: 10.1002/hep. 23008

71 Tominaga K, Kondo C, Johmura Y, Nishizuka M and Imagawa M: The role of gene fad104, containing a fibronectin type III domain, has a significant role in adipogenesis. FEBS Lett 577: 49-54, 2004. PMID: 15527760. DOI: 10.1016/j.febslet.2004.09.062

72 Urtreger AJ, Werbajh SE, Verrechia F, Mauviel A, Puricelli LI, Kornblihtt AR and de Kier Joffe ED: Fibronectin is distinctively downregulated in murine mammary adenocarcinoma cells with highest potential. Oncol Rep 16: 1403-1410, 2006. PMID: 17089068. DOI: $10.3892 /$ or.16.6.1403

73 Gou Y, Zhai F, Zhang L and Cui L: RUNX3 regulates hepatocellular carcinoma cell metastasis via targeting miR-186/Ecadherin/EMT pathway. Oncotarget 8: 61475-61486, 2017. PMID: 28977878. DOI: 10.18632/oncotarget.18424

74 Chen F, Bai J, Li W, Mei P, Liu H, Li L, Pan Z, Wu Y and Zheng $\mathrm{J}$ : RUNX3 suppresses migration, invasion and angiogenesis of 
human renal carcinoma. PLoS One 8: e56241, 2013. PMID: 23457532. DOI: 10.1371/journal.pone.0056241

75 Kim TY, Lee HJ, Hwang KL, Lee M, Kim JW, Bang YJ and Kang GH: Methylation of RUNX3 in various types of human cancers and premalignant stages of gastric carcinoma. Lab Invest 84: 479-484, 2004. PMID: 15122305. DOI: 10.1038/labinvest. 3700108

76 Yang J, Sheng YY, Wie JW, Gao XM, Zhu Y, Jia HL, Dong QZ and Qin LX: MicroRNA-219-5p promotes tumor growth and metastasis of hepatocellular carcinoma by regulating cadherin 1 . Biomed Res Inst 2018: 4793971. PMID: 29862272. DOI: $10.1155 / 2018 / 4793971$

77 Onder TT, Gupta PB, Mani SA, Lander ES and Weinberg RA: Loss of E-cadherin promotes metastasis via multiple downstream transcriptional pathways. Cancer Tes 68: 3645-3654, 2008. PMID: 18483246. DOI: 10.1158/0008-5472.CAN-07-2938

78 Vleminckx K, Vakaet L Jr, Mareel M, Fiers W and van Roy F: Genetic manipulation of E-cadherin expression by epithelial cells reveals an invasion suppressor role. Cell 66: 107-119, 1991. PMID: 2070412. DOI: 10.1016/0092-8674/91 90143-M

79 Giannelli G, Koudelkova P, Dituri F and Mikulitis W: Role of epithelial to mesenchymal transition in hepatocellular carcinoma. J Hepatol 65: 798-808, 2016. PMID: 27212245. DOI: 10.1016/j.jhep.2016.05.007

80 Hakamori S: Glycosylation defining cancer malignancy: new wine in an old bottle. Proc Natl Acad Sci USA 99: 10231-10233, 2002. PMID: 12149. DOI: 10.1073/pnas.172380699

81 Häuselmann I and Borsig L: Altered tumor-cell glycosylation promotes metastasis. Front Oncol 4: 28, 2014. PMID: 24592356. DOI: $10.3389 /$ fonc. 2014.00028

82 Huang H, Liu Y, Yu P, Qu J, Guo Y, Li W, Wang S and Zhang J: MiR-23a transcriptional activated by Runx2 increases metastatic potential of mouse hepatoma cell via directly targeting Mgat3. Sci Rep 8: 7366, 2018. PMID: 29743543. DOI: 10.1038/s41598-01825768-Z

83 Pinho SS, Oliveira P, Cabral J, Huntsman D, Gärtner F, Seruca R, Reis CA and Oliveira C: Loss and recovery of Mgat3 and GnTIII mediated E-cadherin $\mathrm{N}$-glycosylation is a mechanism involved in epithelial-mesenchymal-epithelial transitions. PLoS One 7: e33191, 2012. PMID: 22427986. DOI: 10.1371/journal.pone. 0033191

84 Fang T, Ly H, Ly G, Li T, Wang C, Han Q, Su B, Guo L, Huang S, Cao D, Tang L, Tang S, Wu M, Yang W and Wang H: Tumorderived exosomal $m i R-1247-3 p$ induces cancer-associated fibroblast activation to foster lung metastasis of liver cancer. Nat Commun 9: 191, 2018. PMID: 29335551. DOI: 10.1038/s41467-017-02583-0

85 Chen CH, Wang SH, Liu CH, Wu YL, Wang WJ, Huang J, Hung JS, Lai IR, Liang JT and Huang MC: Galactosyltransferase III suppresses $\beta 1$ integrin-mediated invasive phenotypes and negatively correlates with metastasis in colorectal cancer. Carcinogenesis 35: 1258-1266, 2014. PMID: 24403309. DOI: 10.1093/carcin/bgu007

86 Erez N, Truitt M, Olson P, Arron ST and Hanahan D: Cancerassociated fibroblasts are activated in incipient neoplasia to orchestrate tumor-promoting inflammation in an NF-kappaBdependent manner. Cancer Cell 17: 135-147, 2010. PMID: 20138012. DOI: 10.1016/j.ccr.2009.12.041

87 Räsänen $\mathrm{K}$ and Vaheri A: Activation of fibroblasts in cancer stroma. Exp Cell Res 316: 2713-2722, 2010. PMID: 20451516. DOI: $10.1016 /$ j.yexcr.2010.04.032
88 Zhiu HC, Fang JH, Shang LR, Zhang ZJ, Sang Y, Xu L, Yuan Y, Chen MS, Zheng L, Zhang Y and Zhuang SM: MicroRNAs miR$125 \mathrm{~b}$ and $\mathrm{miR}-100$ suppress metastasis of hepatocellular carcinoma by disrupting the formation of vessels that encapsulate tumor clusters. J Pathol 240: 450-460, 2016. PMID: 27577856. DOI: $10.1002 /$ path.4804

89 Torimura T, Ueno T, Kin M, Harada R, Taniguchi E, Nakamura T, Sakata R, Hashimoto O, Sakamoto M, Kumashiro R, Sata M, Nakashima $\mathrm{O}$, Yano $\mathrm{H}$ and Kojiro $\mathrm{M}$ : Overexpression of angiopoietin-1 and angiopoietin-2 in hepatocellular carcinoma. J Hepatol 40: 799-807, 2004. PMID: 15094228. DOI: 10.1016/j.jhep.2004.01.027

90 Matter MS, Decaens T, Andersen JB and Thoegeirsson SS: Targeting the mTOR pathway in hepatocellular carcinoma: current state and future trends. J Hepatol 60: 855-865, 2014. PMID: 24308993. DOI: 10.1016/j.jhep.2013.11.031

91 Bi Q, Tang S, Xia L, Du R, Fan R, Gao L, Jin J, Liang S, Chen Z, Xu G, Nie W, Wu K, Liu J, Shi Y, Ding j and Fan D: Ectopic expression of $m i R-125 a$ inhibits the proliferation and metastasis of hepatocellular carcinoma by targeting MMP11 and VEGF. PLos One 7: e40169, 2012. PMID: 22768249. DOI: 10.1371/journal.pone.0040169

92 Chow NH, Hsu PI, Lin XZ, Yang HB, Chan SH, Cheng KS, Huang SM and Su IJ: Expression of vascular endothelial growth factor in normal liver and hepatocellular carcinoma: an immunohistochemical study. Human Pathol 28: 698-703, 1997. PMID: 9191004. DOI: 10.1016/S0046-8177/97 90179-9

93 Li XM, Tang ZY, Zhou G, Lui YK and Ye SL: Significance of vascular endothelial growth factor mRNA expression in invasion and metastasis of hepatocellular carchinoma. J Exp Clin Cancer Res 17: 13-17, 1998. PMID: 9646228.

94 Zhang X, Huang S, Guo J, Zhou L, You L, Zhang T and Zhao Y: Insights into the distinct roles of MMP-11 in tumor biology and future therapeutics (Review). Int J Oncol 48: 1783-1793, 2016. PMID: 26892540. DOI: 10.3892/ijo.2016.3400

95 Wang R, Zhao N, Li S, Fang JH, Chen MX, Yang J, Jia WH, Yuan $\mathrm{Y}$ and Zhuang SM: MicroRNA-195 suppresses angiogenesis and metastasis of hepatocellular carcinoma by inhibiting the expression of VEGF, VAV2, and CDC42. Hepatology 58: 642653, 2013. PMID: 23468064. DOI: 10.1002/hep.26373

96 Bishop AL and Hall A: Rho GTPases and their effector proteins. Biochem J 348 Pt 2: 241-255, 2000. PMID: 10816416. DOI: 10.1042/bj3480241

97 Ghosh A, Dasgupta D, Ghosh A, Roychoudhury S, Kumar D, Gorain M, Butti R, Datta S, Agarwal S, Guota S, Krishna Dhali G, Chowdhury A, Schmittgen TD, Kundu GC and Banerjee S: MiRNA199a-3p suppresses tumor growth, migration, invasion and angiogenesis in hepatocellular carcinoma by targeting VEGF, VEGFR1, VEGFR2, HGF and MMP2. Cell Death Dis 8: e2706, 2017. PMID: 28358369. DOI: $10.1038 /$ cddis.2017.123

98 Monvoisin A, Neaud V, De Ledinghen V, Dubuisson L, Balabaud C, Bioulac-Sage P, Desmouliere A and Rosenbaum J: Direct evidence that hepatocyte growth factor-induced invasion of hepatocellular carcinoma cells is mediated by urokinase. J Hepatol 30: 511-518, 1999. PMID: 10190737. DOI: 10. 1016/S0168-8278/99 80113-5

99 Okazaki I and Inagaki Y: Novel strategies for hepatocellular carcinoma based on MMPs science. Anticancer Agents Med Chem 12: 753-763, 2012. PMID: 22292750. DOI: 10.2174/ 187152012802650165 
100 Yan JJ, Zhang YN, Liao JZ, Ke KP, Chang Y, Li PY, Wang M, Lin JS and He XX: MiR-497 suppresses angiogenesis and metastasis of hepatocellular carcinoma by inhibiting VEGFA and ARG-1. Oncotarget 6: 29527-29542, 2015. PMID: 26336827. DOI: $10.18632 /$ oncotarget.5012

101 Sarkar D: AEG1/MTDH/LYRIC in liver cancer. Adv Cancer Res 120: 193-221, 2013. PMID: 23889992. DOI: 10.1016/B978-0-12401676-7.00007-3

102 Liu X, Wang D, Liu H, Feng Y, Zhu T, Zhang L, Zhu B and Zhang Y: Knockdown of astrocyte elevated gene-1 (AEG-1 in cervical cancer cells decreases their invasiveness, epithelial to mesenchymal transition, and chemoresistance. Cell Cycle 13: 1702-1707, 2014. PMID: 24675891. DOI: 10.4161/cc.28607

103 Fang Y, Xue JL, Shen Q, Chen J and Tian L: MicroRNA-7 inhibits tumor growth and metastasis by targeting the phosphoinosite 3-kinase/Akt pathway in hepatocellular carcinoma. Hepatology 55: 1852-1862, 2012. PMID: 22234835. DOI: $10.1002 /$ hep. 25576

104 Engelman JA: Targeting PI3K signalling in cancer: opportunities, challenges and limitations. Nat Rev Cancer 9: 550-562, 2009. PMID: 19629070. DOI: 10.1038/nrc2664

105 Chen X, Wang Y, Tao J, Shi Y, Gai X, Huang F, Ma Q, Zhou Z, Chen H, Zhang H, Liu Z, Sun Q, Peng H, Chen R, Jing Y, Yang $\mathrm{H}$, Mao Y and Zhang H: mTORC1 up-regulates GP73 to promote proliferation and migration of hepatocellular carcinoma cells and growth of xenograft tumors in mice. Gastroenterology 149: 741752, 2015. PMID: 25980751. DOI: 10.1053/j.gastro.2015.05.005

106 Pasquale EB: Eph receptor signalling casts a wide net on cell behaviour. Nat Rev Mol Cell Biol 6: 462-475, 2005. PMID: 15928710. DOI: $10.1038 / \mathrm{nrm} 1662$

107 Yang X, Liang L, Zhang XF, Jia HL, Qin Y, Zhu XC, Gao XM, Qiao P, Zheng Y, ShengYY, Wie JW, Zhou HJ, Ren N, Ye Qh, Dong QZ and Qin LX: MicroRNA-26a suppresses tumor growth and metastasis of human hepatocellular carcinoma by targeting interleukin-6-Stat3 pathway. Hepatology 58: 158-170, 2013. PMID: 23389848. DOI: 10.1002/hep.26305

108 Zhang X, Zhang X, Wang T, Wang L, Tan Z, Wie W, Yan B, Zho J, Wu K, Yang A, Zhang R and Jia L: MicrRNA-26a is a key regulon that inhibits progression and metastasis of c-Myc/EZH2 double high advanced hepatocellular carcinoma. Cancer Lett 426: 98-108, 2018. PMID: 29653269. DOI: 10.1016/j.canlet. 2018.04.005

109 Weidle UH, Klostermann S, Eggle D and Krüger A: Interleukin 6/interleukin 6 receptor interaction and its role as a therapeutic target for treatment of cachexia and cancer. Cancer Genomics Proteomics 7: 287-302, 2010. PMID: 21156962.

110 Liu Y, Li PK, LiC and Lin J: Inhibition of STAT3 signaling blocks the anti-apoptotic activity of IL6 in human liver cancer cells. J Biol Chem 285: 27429-27439, 2010. PMID: 20562100. DOI: 10.1074/jbc.M110.142752

$111 \mathrm{Xu}$ W, Wang Z, Zhang W, Qian K, Li H, Kong D, Li Y and Tang Y: Mutated K-ras activates CDK8 to stimulate the epithelial-tomesenchymal transition in pancreatic cancer in part via the Wnt/ $\beta$-catenin signaling pathway. Cancer Lett 356: 613-627, 2015. PMID: 25305448. DOI: 10.1016/j.canlet.2014.10.008

112 Sato M, Matsuda Y, Wakai T, Kubota M, Osawa M, Fujimaki S, Sanpei A, Takamura M, Yamagiwa S and Aoyagi Y: P21-activated kinase-2 is a critical mediator of transforming growth factor- $\beta$ induced hepatoma cell migration. J Gastroenterol Hepatol 28 1047-1055, 2013. PMID: 23425030. DOI: 10.1111/jgh.12150
113 Gao SB, Zheng QF, Xu B, Pan CD, Li KL, Zhao Y, Zheng Y, Zheng QL, Lin X, Xue LX and Jin GH: EZH2 represses target genes through $\mathrm{H} 3 \mathrm{~K} 27$-dependent and H3K27-independant mechanisms in hepatocellular carcinoma. Mol Cancer Res 12: 1388-1397, 2014. PMID: 24916103. DOI: 10.1158/15417786.MCR-14-0034

114 Au SL, Wong CC, Lee JM, Fan DN, Tsang FH, Ng IO and Wong CM: Enhancer of zeste homolog 2 epigenetically silences multiple tumor suppressor microRNAs to promote liver cancer metastasis. Hepatology 56: 622-631, 2012. PMID: 22370893. DOI: $10.1002 /$ hep.25679

115 Yang P, Li QJ, Feng Y, Zhang Y, Markowitz GJ, Ning S, Deng Y, Zhao J, Jiang S, Yuan Y, Wang HY, Cheng SQ, Xie D and Wang XF: TGF- $\beta$-miR-34a-CCL2 signaling-induced Treg cell recruitment promotes venous metastases of $\mathrm{HBV}$-positive hepatocellular carcinoma. Cancer Cell 22: 291-303, 2012. PMID: 22975373. DOI: $10.1016 /$ j.ccr.2012.07.023

116 Matsuzki K: Modulation of TGF $\beta$ signaling during progression of chronic liver diseases. Front Biosci (Landmark Ed): 14: 29232934, 2009. PMID: 19273245. DOI: $10.2741 / 3423$

117 Mailloux AW and Young MR: Regulatory T-cell trafficking: from thymic development to tumor-induced immune suppression. Crit Rev Immunol 30: 435-447, 2010. PMID: 21083525.

118 Zhou HC, Fang JH, Luo X, Zhang L, Yang J, Zhang C and Zhuang SM: Downregulation of microRNA-100 enhances the ICMT-Rac1 signaling and promotes metastasis of hepatocellular carcinoma cells. Oncotarget 5: 12177-12188, 2014. PMID: 25361001.

119 Winter-Vann AM and Casey PJ: Post-prenylation-processing enzymes as new targets in oncogenesis. Nat Rev Cancer 5: 405412, 2005. PMID: 15864282 . DOI: $10.1038 / \mathrm{nrc} 1612$

120 Wang M, Hossain MS, Tan W, Coolman B, Zhou J, Liu S and Casey PJ: Inhibition of isoprenylcysteine carboxylmethyltransferase induces autophagic-dependent apoptosis and impairs tumor growth. Oncogene 29: 4959-4970, 2010. PMID: 20622895. DOI: $10.1038 /$ onc. 2010.247

121 Nobes CD and Hall A: Rho, rac and cdc42 GTPases regulate the assembly of focal complexes with actin stress fibers, lamellipodia, and filopodia. Cell 81: 53-62, 1995. PMID: 7536630.

122 Tolias KF, Cantley LC and Charpenter CL: Rho family GTPaes bind to phosphoinositide kinases. J Biol Chem 270: 17656-17659, 1995. PMID: 7629060. DOI: 10.1074/jbc.270.30.17656

123 Zheng F, Liao YJ, CaiMY, Liu TH, Chen SP, Wu PH, Wu L, Bian XW, Guan XY, Zeng YX, Yuan YF, Kung HF and Xie D: Systemic delivery of microRNA-101 potently inhibits hepatocellular carcinoma by repressing multiple targets. PLoS Genet 11: e1004873, 2015. PMID: 25693145. DOI: 10.1371/journal.pgen.1004873

124 Wong CC, Wong CM, Tung EK, Au SL, Lee JM, Poon RT, Man $\mathrm{K}$ and $\mathrm{Ng}$ IO: The microRNA miT-139 suppresses metastasis and progression of hepatocellular carcinoma by down-regulating Rhokinase 2. Gastroenterology 140: 322-331, 2011. PMID: 20951699. DOI: $10.1053 /$ j.gastro.2010.10.006

125 Leung T, Chen XQ, Manser E and Lim L: The p160 RhoA-binding kinase ROK alpha is a member of a kinase family and is involved in the reorganization of the cytoskeleton. Mol Cell Biol 16: 53135327, 1996. PMID: 8816443. DOI: 10.1128/MCB.16.10.5313

126 Wong CC, Wong CM, Tung EK, Man K and Ng IO: Rho-linase 2 is frequently overexpressed in hepatocellular carcinoma and involved in tumor invasion. Hepatology 49: 1583-1594, 2009. PMID: 19205033. DOI: 10.1002/hep.22836 
127 Cui S, Zhang K, Li C, Chen J, Pan Y, Feng B, Lu L, Zhu Z, Wang $\mathrm{R}$ and Chen L: Methylation-associated silencing of microRNA129-3p promotes epithelial-mesenchymal transition, invasion and metastasis of heptocellular cancer by targeting Aurora-A. Oncotarget 7: 78009-78028, 2016. PMID: 27793005. DOI: 10.18632/oncotarget.12870

128 Saeki T, Ouchi M and Ouchi T: Physiological and oncogenic Aurora-A pathway. Int J Biol Sci 5: 758-762, 2009. PMID: 20011137. DOI: 10.7150/ijbs.5.758

129 Wang R, Wang JH, Chu XY, Geng HC and Chen LB: Expression of STK 15 mRNA in hepatocellular carcinoma and its prognostic significance. Clin Biochem 42: 641-647, 2009. PMID: 19232520. DOI: $10.1016 /$ j.clinbiochem.2009.01.023

130 Gao P, Wang R, Shen JJ, Lin F, Wang X, Dong K and Zhang HZ: Hypoxia-inducible enhancer/alpha fetoprotein promoter-driven RNA interference targeting STK15 suppresses proliferation and induces apoptosis in human hepatocellular carcinoma cells. Cancer Sci 99: 2209-2217, 2008. PMID: 18803637. DOI: 10.1111/j.1349-7006.2008.00941.x

131 Liu LL, Lu SX, Li M, Li LZ, Fu J, Hu W, Yang YZ, Luo RZ, Zhang CZ and Yun JP: FoxD3-regulated microRNA-137 suppresses tumor growth and metastasis in human hepatocellular carcinoma by targeting AKT2. Oncotarget 5: 5113-5124, 2014. PMID: 24970808. DOI: 10.18632/oncotarget.2089

132 Manning BD and Cantley LC: AKT/PKB signaling: Navigating downstream. Cell 129: 1261-1274, 2007. PMID: 17604717. DOI: 10.1016/j.cell.2007.06.009

133 Arboleda MJ, Lyons JF, Kabbinavar FF, Bray MR, Snow BE, Ayala R, Danino M, Karlan BY and Slamon DJ: Overexpression of AKT2/protein kinase Bbeta leads to up-regulation of beta1 integrins, increased invasion, and metastasis of human breast and ovarian cancer cells. Cancer Res 63: 196-206, 2003. PMID: 12517798.

$134 \mathrm{Xu}$ X, Sakon M, Nagano H, Hiraoka N, Yamamoto H, Hayashi N, Dono K, Nakamori S, Umeshita K, Itoh Y, Matsuura $\mathrm{N}$ and Monden M: Akt2 expression correlates with prognosis of human hepatocellular carcinoma. Oncol Rep 11: 25-32, 2004. PMID: 14654898. DOI: 10.3892/or.11.1.25

135 Tao ZH, Wan JL, Zeng LY, Xie L, Sun HC, Qin LX, Wang L, Zhou J, Ren ZG, Li YX, Fan J and Wu Z: miR-612 suppresses the invasive-metastatic cascade in hepatocellular carcinoma. J Exp Med 210: 789-803, 2013. PMID: 23478189. DOI: 10.1084/ jem.20120153

136 Luo G, Chao YL, Tang B, Li BS, Xiao YF, Xie R, Wang SM, Wu YY, Dong H, Liu XD and Yang SM: miR-149 represses metastasis of hepatocellular carcinoma by targeting actin-regulatory proteins PPM1F. Oncotarget 6: 37808-37823, 2015. PMID: 26498692. DOI: $10.18632 /$ oncotarget.5676

137 Xie Y, Tan EJ, Wee S, Manser E, Lim L and Koh CG: Functional interactions between phosphatase POPX2 and mDia modulate RhoA pathways. J Cell Sci 121: 514-521, 2008. PMID: 18230650. DOI: $10.1242 /$ jcs.013557

138 Phang HQ, Hoon JL, Lai SK, Zeng Y, Chiam KH, Li HY and Koh CG: POPX2 phosphatase regulates the KIF3 kinesin motor complex. J Cell Sci 127: 727-739, 2014. PMID: 24338362. DOI: $10.1242 /$ jcs. 126482

139 Sun W, Zhang Z, Wang J, Shang R, Zou L, Wang X, Duan J, Ruan B, Gao Y, Dai B, Qu S, Liu W, Ding R, Wang L, Wang D and Dou K: MicroRNA-150 suppresses cell proliferation and metastasis in hepatocellular carcinoma by inhibiting the GAB1-
ERK axis. Oncotarget 7: 11595-115608, 2016. PMID: 26871477. DOI: $10.18632 /$ oncotarget.7292

$140 \mathrm{Gu} \mathrm{H}$ and Neel BG: The „Gab“ in signal transduction. Trends Cell Biol 13: 122-130, 2003. PMID: 12628344. DOI: 10.1016/S09628924/03 00002-3

141 Felici A, Giubellino and Bottaro DP: Gab1 mediates hepatocyte growth factor-stimulated mitogenicity and morphogenesis in multipotent myeloid cells. J Cell Biochem 111: 310-321, 2010. PMID: 20506405. DOI: 10.1002/jcb.22695

142 Fang F, Chang RM, Yu L, Lei X, Xiao S, Yang H and Yang LY: MicroRNA-188-5p suppresses tumor cell proliferation and metastasis by directly targeting FGF5 in hepatocellular carcinoma. J Hepatol 63: 874-885, 2015. PMID: 25998163. DOI: 10.1016/j.jhep.2015.05.008

143 Kornmann M, Ishiwata T, Beger HG and Kork M: Fibroblast growth factor-5 stimulates mitogenic signaling and is overexpressed in human pancreatic cancer. Oncogene 15: 14171427, 1997. PMID: 9333017. DOI: 10.1038/sj.onc.1201307

144 Yu M, Xue H, Wang Y, Shen Q, Jiang Q, Zhang X, Li K, Jia M, Jia J, Xu J, Tian Y: miR-345 inhibits tumor metastasis and EMT by targeting IRF1-mediated mTOR/STAT3/AKT pathway in hepatocellular carcinoma. Int J Oncol 50: 975-983, 2017. PMID: 28098858. DOI: $10.3892 /$ ijo.2017.3852

145 Kröger A, Ortmann D, Krohne TU, Mohr L, Blum HE, Hauser H and Geissler M: Growth suppression of the hepatocellular carcinoma cell line Hepa1-6 by an activatable interferon regulatory factor-1 in mice. Cancer Res 61: 2609-2617, 2001. PMID: 11289138.

146 Zhang $\mathrm{H}$, Liu $\mathrm{H}$ and $\mathrm{Bi} \mathrm{H}$ : MicroRNA-345 inhibits hepatocellular carcinoma metastasis by inhibiting YAP1. Oncol Rep 38: 843-849, 2017. PMID: 28677785. DOI: 10.3892/ or.2017.5772

147 Harvey KF, Zhang X and Thomas DM: The Hippo pathway and human cancer. Nat Rev Cancer 13: 246-257, 2013. PMID: 23467301. DOI: $10.1038 / \mathrm{nrc} 3458$

148 Farazi PA and DePinho RA: Hepatocellular carcinoma pathogenesis: from genes to environment. Nat Rev Cancer 6: 674687, 2006. PMID: 16929323. DOI: 10.1038/nrc1934

$149 \mathrm{Xu}$ J, Lin H, Li G, Chen J, Shi L, Cai X and Chang C: The miR367-3p increases sorafenib chemotherapy efficacy to uppress hepatocellular carcinoma metastasis through altering the androgen receptor signals. EBioMedicine 12: 55-67, 2016. PMID: 27688096. DOI: 10.1016/j.ebiom.2016.07.013

150 Wade M, Li YC and Wahl GM: MDM2, MDMX and p53 in oncogenesis and cancer therapy. Nat Rev Cancer 13: 83-96, 2013. PMID: 23303139. DOI: 10.1038/nrc3430

151 Lin HK, Wang L, Hu YC and Chang C: Phosphorylationdependent ubiquitinylation and degradation of androgen receptor by Akt require Mdm2 E3 ligase. EMBO J 21: 4037-4048, 2002. PMID: 12145204. DOI: $10.1093 / \mathrm{emboj} / \mathrm{cdf} 406$

152 Chen JS, Li HS, Huang JQ, Dong SH, Huang ZJ, Yi W, Zhan GF, Feng JT, Sun JC and Huang XH: MicroRNA-379$5 \mathrm{p}$ inhibits tumor invasion and metastasis by targeting FAK/AKT signaling in hepatocellular carcinoma. Cancer Lett 375: 73-83, 2016. PMID: 26944318. DOI: $10.1016 /$ j.canlet .2016 .02 .043

153 Panera N, Crudele A, Romito I, Gnani D and Alisi A: Focal adhesion kinase: Insight into molecular roles and functions in hepatocellular carcinoma. Int J Mol Sci 18: pii E99, 2017. PMID: 28067792. DOI: $10.3390 /$ ijms18010099 
154 Zhang J, Yang Y, Yang T, Yuan S, Wang R, Pan Z, Yang y, Huang G, Gu F, Jing B, Lin C and Zhou W: Double-negative feedback loop between microRNA-422a and forkhead box (FOX)G1/Q1/E1 regulates hepatocellular carcinoma tumor growth. Hepatology 61: 561-573, 2015. PMID: 25251503. DOI: 10.1002/hep.27491

155 Xia L, Huang W, Tian D, Zhang L, Qi X, Chen Z, Shang X, Nie $\mathrm{Y}$ and $\mathrm{Wu} \mathrm{K}$ : Forkhead box Q1 promotes hepatocellular carcinoma metastasis by transactivating ZEB2 and Versican V1 expression. Hepatology 59: 958-973, 2014. PMID: 24005989. DOI: 10.1002/hep.26735

156 Zhou J, Tao Y, Peng C, Gu P and Wang W: miR-503 regulates metastastatic function through Rho guanine nucleotide exchanger factor 19 in hepatocellular carcinoma. J Surg Res 188: 129-136, 2014. PMID: 24405610. DOI: 10.1016/j.jss.2013.12.006

157 Ellenbroek SI and Collard JG: Rho GTPases: functions and association with cancer. Clin Exp Metastasis 24: 657-672, 2007. PMID: 18000759. DOI: 10.1007/s10585-007-9119-1

158 Wang W, Wu F, Fang F, Tao Y and Yang L: Inhibition of invasion and metastasis of hepatocellular carcinoma cells via targeting RhoC in vitro and in vivo. Clin Cancer Res 14: 6804-6812, 2008. PMID: 18980974. DOI: 10.1158/1078-0432.CCR-07-4820

159 Zhang Z, Yin J, Yang J, Shen W, Zhang C, Mou W, Luo J, Yan $\mathrm{H}$, Sun $\mathrm{P}$, Tian $\mathrm{Y}$ and Xiang R: miR-885-5p suppresses hepatocellular carcinoma metastasis and inhibits Wnt/ $/$-catenin pathway. Oncotarget 7: 75038-75051, 2016. PMID: 27738331. DOI: $10.18632 /$ oncotarget.12602

160 Chen J, Rajasekaran M and Hui KM: Atypical regulators of $\mathrm{Wnt} / \beta$-catenin as potential targets in hepatocellular carcinoma Exp Biol Med (Maywood) 242: 1142-1149, 2017. PMID: 28429652. DOI: $10.1177 / 1535370217705865$

161 Zou ZC, Dai M, Huang ZY, Lu Y, Xie HP, Li YF, Tan Y and Wang FL: MicroRNA-139-3p suppresses tumor growth and metastases in hepatocellular carcinoma by repressing ANXA2R. Oncol Res 2018, ahead of print. PMID: 29422116. DOI: 10.3727/096504018X15178798885361

162 Shiozawa Y, Havens AM, Jung Y, Ziegler AM, Pedersen EA, Wang J, Wang J, Lu G, Roodman GD, Loberg RD, Pienta KJ and Taichman RS: Annexin II/annexin II receptor axis regulates adhesion, migration, homing and growth of prostate cancer. J Cell Biochem 105: 370-380, 2008. PMID: 18636554. DOI: 10.1002/jcb. 21835

163 Zhang JP, Zeng C, Xu L, Gong J, Fang JH and Zhuang SM: MicroRNA-148a suppresses epithelial-mesenchymal transition and metastasis of hepatoma cells by targeting Met/Snail signaling. Oncogene 33: 4069-4076, 2014. PMID: 24013226. DOI: 10.1038/onc.2013.369

164 Jiang H, Zhou Z, Jin S, Xu K, Zhang H, Xu J, Sun Q, Wang J and $\mathrm{Xu}$ J: PRMT9 promotes hepatocellular carcinoma invasion and metastasis via activating PI3K/Akt/GSK-3 $\beta /$ Snail signaling. Cancer Sci 109: 1414-1427, 2918. PMID: 29603830. DOI: 10.1111/cas.13598

165 Dou C, Liu Z, Xu M, Jia Y. Wang Y, Li Q, Yang W, Zheng X, Tu $\mathrm{K}$ and Liu Q: $m i R-187-3 p$ inhibits the metastasis and epithelialmesenchymal transition of hepatocellular carcinoma by targeting S100A4. Cancer Lett 381: 380-390, 2016. PMID: 27544906. DOI: 10.1016/j.canlet.2016.08.011

166 Fei F, Qu J, Zhang M, Li Y and Zhang S: S100A4 in cancer progression and metastasis: A systematic review. Oncotarget 8 : 73219-73239, 2017. PMID: 29069865. DOI: 10.18632/ oncotarget. 18016
167 Lian J, Jing Y, Dong Q, Huan L, Chen D, Bao C, Wang Q, Zhao F, Li J, Yao M, Qin L, Liang L and He X: $m i R-192$, a prognostic indicator, targets the SLC39A6/SNAIL pathway to reduce tumor metastasis in human hepatocellular carcinoma. Oncotarget 7: 2672-2683, 2016. PMID: 26684241. DOI: 10.18632/oncotarget. 6603

168 Grattan BJ and Fraeke HC: Zinc and cancer. Implications for LIV1 in breast cancer. Nutrients 4: 648-675, 2012. PMID: 22852056. DOI: $10.3390 /$ nu 4070648

169 Hogstrand C, Kille P, Ackland ML, Hiscox S and Taylor KM: A mechanism for epithelial-mesenchymal transition and anoikis resistance in breast cancer triggered by zinc channel ZIP6 and STAT3 (signal transducer and activator of transcription 3). Biochem J 455: 229-237, 2013. PMID: 23919497. DOI: $10.1042 / B J 20130483$

170 Yang X, Wang J, Qu S, Zhang H, Ruan B, Gao Y, Ma B, Wang $\mathrm{X}, \mathrm{Wu} \mathrm{N}, \mathrm{LiX}$, Dou K and Li H: MicroRNA-200a suppresses metastatic potential of side population cells in human heatocellular carcinoma by decreasing ZEB2. Oncotarget 6: 79187929, 2015. PMID: 25797260. DOI: 10.18632/oncotarget.3486

171 Kim CG, Lee H, Gupta N, Ramachandran S, Kaushik I, Srivastava S, Kim SH and Srivastava SK: Role of Forkhead Box Class $\mathrm{O}$ proteins in cancer progression and metastasis. Sem Cancer Biol 50: 142-151, 2018. PMID: 28774834. DOI: 10.1016/j.semcancer.2017.07.007

172 Chou YS and Yang MH: Epithelial-mesenchymal transitionrelated factors in solid tumor and hematological malignancy. J Chin Med Assoc 78: 438-445, 2015. PMID: 26078096. DOI: 10.1016/j.jcma.2015.05.002

173 Shi JH, Huitfeldt HS, Suo ZH and Line PD: Growth of hepatocellular carcinoma in the regenerating liver. Liver Transpl 17: 866-874, 2011. PMID: 21542129. DOI: 10.1002/lt.22325

174 Zheng XB, Chen XB, Xu LL, Zhang M, Feng L, Yi PS, Tang JW and $\mathrm{Xu}$ MQ: $m i R-203$ inhibits augmented proliferation and metastasis of hepatocellular carcinoma residual in the promoted regeneration liver. Cancer Sci 108: 338-346, 2017. PMID: 28100026. DOI: $10.1111 /$ cas.13167

175 Chen SP, Liu BX, Xu J, Pei XF, Liao YJ, Yuan F and Zheng F: MiR-449a suppresses the epithelial-mesenchymal transition and metastasis of hepatocellular carcinoma by multiple targets. BMC Cancer 15: 706, 2015. PMID: 26471185. DOI: $10.1186 / \mathrm{s} 12885-$ 015-1738-3

176 Yuen MF, Wu PC, Lai VC, Lau JY and Lai CL: Expression of cMyc, c-Fos, and c-jun in hepatocellular carcinoma. Cancer 91: 106-112, 2001. PMID: 11148566. DOI: 10.1002/10970142(20010101)91:1<106::aid-cncr14>3.0.co;2-2

177 Peters ME and Adjei AA: MET: a promising anticancer therapeutic target. Nat Rev Clin Oncol 9: 314-326, 2012. PMID: 22566105. DOI: $10.1038 /$ nrclinonc.2012.71

178 Luo C, Yin D, Zhan H, Borjigin U, Li C, Zhou Z, Hu Z, Wang P, Sun Q, Fan J, Zhou J, Wang X, Zhou S and Huang X: microRNA501-3p suppresses metastasis and progression of hepatocellular carcinoma through targeting LIN7A. Cell Death Dis 9: 535, 2018. PMID: 29749382. DOI: 10.1038/s41419-018-0577-y

179 Martin-Belmonte F and Perez-Moreno M: Epithelial cell polartity, stem cells and cancer. Nat Rev Cancer 12: 23-28, 2011. PMID: 22169974. DOI: $10.1038 /$ nrc3169

180 Chen WX, Zhang ZG, Ding ZY, Liang HF, Song J, Tan XL, Wu JJ, Li GZ, Zheng Z, Zhang BX and Chen XP: MicroNA-630 suppresses tumor metastasis through the TGF- $\beta$-miR 630-Slug 
signaling pathway and correlates inversely with poor prognosis in hepatocellular carcinoma. Oncotarget 7: 22674-22686, 2016. PMID: 26993767. DOI:10.18632/oncotarget.8047

181 Bolos V, Peinado H, Perez-Moreno MA, Fraga MF, Esteller M and Cano A: The transcription factor Slug represses E-cadherin expression and induces epithelial to mesenchymal transitions: a comparison with Snail and E47 repressors. J Cell Sci 116: 499511, 2003. PMID: 12508111. DOI: 10.1242/jcs.00224

$182 \mathrm{Li} \mathrm{C}$, Jiang Y, Miao R, Zhang J and Liu C: MicroRNA-1271 functions as a metastases and epithelial-mesenchymal transition inhibitor in human HCC by targeting PTP4A1/c-Src axis. Int J Oncol 52: 536-546, 2018. PMID: 29345291. DOI: 10.3892/ ijo.2017.4224

183 Hardy S, Konstantin E, Hatzihristidis T, Zolotarov Y, Uetani N and Tremblay ML: Physiological and oncogenic roles of PRL phosphatases. FEBS J 285: 3886-3908, 2018. PMID: 29770564. DOI: $10.1111 /$ febs.14503

184 Xu Q, Liu X, Liu Z, Zhou Z, Wang Y, Tu L, Bao H, Yang L and Tu K: MicroRNA-1296 inhibits metastasis and epithithelialmesenchymal transition of hepatocellular carcinoma by targeting SRPK1-mediated PI3K/AKT pathway. Mol Cancer 16: 103, 2017. PMID: 28606154. DOI: 10.1186/s12943-017-0675-y

185 Zhou B, Li Y, Deng Q, Wang H, Wang Y, Cai B and Han ZG: SRPK1 contributes to malignancy of hepatocellular carcinoma through a possible mechanism involving PI3K/Akt. Mol Cell Biochem 379: 191-199, 2013. PMID: 23644876. DOI: 10.1007/s11010-013-1641-7

186 Peng YF, Shi YH, Ding ZB, Ke AW, Gu CY, Hui B, Zhou J, Qiu SJ, Dai $Z$ and Fan J: Autophagy inhibition suppresses pulmonary metastasis of HCC in mice via impairing anoikis resistance and colonization of HCC cells. Autophagy 9: 2056-2068, 2013. PMID: 24157892. DOI: 10.4161/auto.26398

187 Fu XT, Shi YH, Zhou J, Peng YF, Liu WR, Shi GM, Gao Q, Wang XY, Song K, Fan J and Ding ZB: MicroRNA-30a suppresses autophagy-mediated anoikis resistance and metastasis in hepatocellular carcinoma. Cancer Lett 412: 108-117, 2018. PMID: 29061507. DOI: 10.1016/j.canlet.2017.10.012

188 Tsai WC, Hsu PW, lai TC, Chau GY, Lin CW, Chen CM, Lin CD, Liao YL, Wang JL, Chau YP, Hsu MT, HsiaoM, Huang HD and Tsou AP: MicroRNA-122, a tumor suppressor microRNA that regulates intrahepatic metastasis of hepatocelular carcinoma. Hepatology 49: 1571-1582, 2009. PMID: 19296470. DOI: 10.1002/hep.22806

189 Black RA, Rauch CT, Kozlosky CJ, Peschon JJ, Slack JL, Wolfson MF, Castner BJ, Stocking KL, Reddy P, Srinivasan S, Nelson N, Boiani N, Schooley KA, Gerhart M, Davis R, Fitzner JN, Johnson RS, Paxton RJ, March CJ and Cerretti DP: A metalloproteinase disintegrin that releases tumor-necrosis factoralpha from cells. Nature 385: 729-733, 1997. PMID: 9034190. DOI: $10.1038 / 385729 \mathrm{a} 0$

190 Borrell-Pages M, Rojo F, Albabell J, Baselga J and Arribas J: TACE is required for the activation of the EGFR by TGF-alpha in tumors. EMBO J 22: 1114-1124, 2003. PMID: 12606576. DOI:10.1093/emboj/cdg111

191 Huang J, Bridges LC and White JM: Selective modulation of integrin-mediated cell migration by distinct ADAM family members. Mol Biol Cell 16: 4982-4991, 2005. PMID: 16079176. DOI: $10.1091 / \mathrm{mbc} . \mathrm{e} 05-03-0258$

192 Blanchot-Jossic F, Jarry A, Masson D, Bach-Ngohou K, Paineau $\mathrm{J}$, Denis MG, Laboisse $\mathrm{CL}$ and Mosnier: Up-regulated expression of ADAM17 in human colon carcinoma: coexpression with EGFR in neoplastic and endothelial cells. J Pathol 207: 156-163, 2005. PMID: 16041691. DOI: 10.1002/ path. 1814

193 Zhang S, Ge W, Zou G, Yu L, Zhu Y, Li Q, Zhang Y, Wang Z and $\mathrm{Xu}$ T: MiR-382 targets GOLM1 to inhibit metastasis of hepatocellular carcinoma and its downregulation predicts a poor survival. Am J Cancer Res 8: 120-131, 2018. PMID: 29416925.

194 Zhu W and Qin L: GOLM1-regulated EGFR/RTK recycling is a novel target for combating HCC metastasis. Sci China Life Sci 50: 98-101, 2017. PMID: 27858335. DOI: 10.1007/s11427-0160311-X

$195 \mathrm{Li} \mathrm{Z}$ and Rana TM: Therapeutic targeting of microRNAs: current status and future challenges. Nat Rev Drug Discov 13: 622-638, 2014. PMID: 25011539. DOI: $10.1038 / \mathrm{nrd} 4359$

196 Gambari R, Brognara E, Spandidos DA and Fabbri E: Targeting oncomiRNAs and mimicking tumor suppressor miRNA: New trends in the development of therapeutic strategies in oncology (Review). Int J Oncol 49: 5-32, 2016. PMID: 27175518. DOI: 10.3892/ijo.2016.3503

197 Ling H, Fabbri and Calin GA: MicroRNAs and other non-coding RNAs as targets for anti-cancer drug development. Nat Rev Drug Discov 12: 847-865, 2013. PMID: 24172333. DOI: 10.1038/ $\operatorname{nrd} 4140$

198 Warner KD, Hajdin CE and Weeks KM: Principles for targeting RNA with drug-like small molecules. Nat Rev Drug Discov 17: 547-558, 2018. PMID: 29977051. DOI: 10.1038/nrd.2018.93

199 Cheng CJ, Bahal R, Babar IA, Pincus Z, Barrera F, Liu C, Svoronos A, Braddock DT, Glazer PM, Engelman DM, Saltzman WM and Slack FJ: MicroRNA silencing for cancer therapy targeted to the tumor microenvironment. Nature 518: 107-110, 2015. PMID: 25409146. DOI: 10.1038/nature13905

200 Scaggiante B, Dapas, Farra R, Grassi M, Pozzato G, Gisante C, Fiotti $\mathrm{N}$ and Grassi G: Improving siRNA bio-distribution and minimizing side effects. Curr Drug Met 12: 11-23, 2011. PMID: 21222588. DOI: $10.2174 / 138920011794520017$

201 Jackson AL and Linsley PS: Recognizing and avoiding siRNA off-target effects for target identification and therapeutic application. Nat Rev Drug Discov 9: 57-67, 2010. PMID: 20043028. DOI: $10.1038 /$ nrd3010

202 Bochicchio S, Dalmoro AA, Grassi G and Lamberti G: Liposomes as siRNA delivery vectors. Curr Drug Metab 15: 882892, 2014. PMID: 25658127. DOI: $10.2174 / 13892002166$ 66150206124913

203 Garafalo M, Leva GD and Croce CM: MicroRNAs as anti-cancer therapy. Curr Pharm Des 20: 5328-5335, 2014. PMID: 24479801. DOI: $10.2174 / 1381612820666140128211346$

204 Scarabel L, Perrone F, Graziera M, Farra R, Grassi M, Musiani F, Russo Spena C, Salis B, De Stefano L, Toffioli G, Rizzolio F, Tonon F, Abrami M, Chiarappa G, Pozzato G, Forte G, Grassi G and Dapas B: Strategies to optimize siRNA delivery to hepatocellular carcinoma cells. Expert Opin Drug Del 14: 797-810, 2017. PMID: 28266887. DOI: 10.1080/17425247.2017.1292247

205 Farra R, Grassi M, Grassi G and Dapas B: Therapeutic potential of small interfering RNA/micro interfering RNA in hepatocellular carcinoma. World J Gastroenterol 21: 8994-9001, 2015. PMID: 26290628. DOI: 10.3748/wjg.v21.i30.8994

206 Crooke ST, Witztum JL, Bennett CF, Baker BF: RNA-targeted therapeutics. Cell Metab 27(4): 714-739, 2018. PMID: 29617640. DOI: $10.1016 /$ j.cmet.2018.03.004 
207 Dowdy SF: Overcoming cellular barriers for RNA therapeutics. Nat Biotechnol 35(3): 222-229, 2017. PMID: 28244992. DOI: 1038/nbt.3802

208 Bennett CF: Therapeutic antisense oligonucleotides are coming of age. Annu Rev Med 70: 307-321, 2019. PMID: 30691367 DOI: 10.1146/annurev-med-041217-010829

209 Crooke ST, Wang S, Vickers TA, Shen W, Liang XH: Cellular uptake and trafficking of antisense oligonucleotides. Nat Biotechnol 35(3): 230-237, 2017. PMID: 28244996. DOI: 10. 1038/nbt.3779

210 Juliano RL: Intracellular trafficking and endosomal release of oligonucleotides: What we know and what we don't. Nucleic Acid Ther 28(3): 166-177, 2018. PMID: 29708838. DOI: 10.1089/ nat.2018.0727

211 Linnane E, Davey P, Zhang P, Puri S, Edbrooke M, Chiarparin E, Revenko AS, Macleod AR, Norman JC, Ross SJ: Differential uptake, kinetics and mechanisms of intracellular trafficking of next-generation antisense oligonucleotides across human cancer cell lines. Nucleic Acids Res 47(9): 4375-4392, 2019. PMID: 30927008. DOI: $10.1093 / \mathrm{nar} / \mathrm{gkz} 214$
212 Buntz A, Killian T, Schmid D, Seul H, Brinkmann U, Ravn J, Lindholm M, Knoetgen H, Haucke V, Mundigl O: Quantitative fluorescence imaging determines the absolute number of locked nucleic acidoligonucleotides needed for suppression of target gene expression. Nucleic Acids Res 47(2): 953-969, 2019. PMID: 30462278. DOI: $10.1093 / \mathrm{nar} / \mathrm{gky} 1158$

213 Malek A, Merkel O, Fink L, Czubayko F, Kissel T and Aigner A: In vivo pharmakinetics, tissue distribution and underlying mechansisms of various PE(-PEG)siRNA complexes. Toxicol Appl Pharmacol 236: 97-108, 2009. PMID: 19371615. DOI: 10.1016/j.taap.2009.01.014

214 Jones D: Setbacks shadow microRNA therapies in the clinic. Nat Biotechnol 36: 909-910, 2018. PMID: 30307922. DOI: 10.1038/ nbt1018-909

Received September 19, 2019

Revised October 31, 2019

Accepted November 4, 2019 